\title{
Apoptosis is not conserved in plants as revealed by critical examination of a model for plant apoptosis-like cell death
}

Elena A. Minina ${ }^{1,2^{*} \dagger}$, Adrian N. Dauphinee ${ }^{1 \dagger}$, Florentine Ballhaus ${ }^{1}$, Vladimir Gogvadze ${ }^{3,4}$, Andrei P. Smertenko ${ }^{5}$ and Peter V. Bozhkov ${ }^{1 *}$ (I)

\begin{abstract}
Background: Animals and plants diverged over one billion years ago and evolved unique mechanisms for many cellular processes, including cell death. One of the most well-studied cell death programmes in animals, apoptosis, involves gradual cell dismantling and engulfment of cellular fragments, apoptotic bodies, through phagocytosis. However, rigid cell walls prevent plant cell fragmentation and thus apoptosis is not applicable for executing cell death in plants. Furthermore, plants are devoid of the key components of apoptotic machinery, including phagocytosis as well as caspases and $\mathrm{BCl}-2$ family proteins. Nevertheless, the concept of plant "apoptosis-like programmed cell death" (AL-PCD) is widespread. This is largely due to superficial morphological resemblances between plant cell death and apoptosis, and in particular between protoplast shrinkage in plant cells killed by various stimuli and animal cell volume decrease preceding fragmentation into apoptotic bodies.
\end{abstract}

Results: Here, we provide a comprehensive spatio-temporal analysis of cytological and biochemical events occurring in plant cells subjected to heat shock at $40-55^{\circ} \mathrm{C}$ and $85^{\circ} \mathrm{C}$, the experimental conditions typically used to trigger $\mathrm{AL}$ PCD and necrotic cell death, respectively. We show that cell death under both conditions was not accompanied by membrane blebbing or formation of apoptotic bodies, as would be expected during apoptosis. Instead, we observed instant and irreversible permeabilization of the plasma membrane and ATP depletion. These processes did not depend on mitochondrial functionality or the presence of $\mathrm{Ca}^{2+}$ and could not be prevented by an inhibitor of ferroptosis. We further reveal that the lack of protoplast shrinkage at $85^{\circ} \mathrm{C}$, the only striking morphological difference between cell deaths induced by $40-55^{\circ} \mathrm{C}$ or $85^{\circ} \mathrm{C}$ heat shock, is a consequence of the fixative effect of the high temperature on intracellular contents.

\footnotetext{
*Correspondence: alena.minina@slu.se; peter.bozhkov@slu.se

${ }^{\dagger}$ Elena A. Minina and Adrian N. Dauphinee contributed equally to this work. 'Department of Molecular Sciences, Uppsala BioCenter, Swedish University of Agricultural Sciences and Linnean Center for Plant Biology, P.O. Box 7015, SE-750 07 Uppsala, Sweden

Full list of author information is available at the end of the article
}

(c) The Author(s). 2021 Open Access This article is licensed under a Creative Commons Attribution 4.0 International License, which permits use, sharing, adaptation, distribution and reproduction in any medium or format, as long as you give appropriate credit to the original author(s) and the source, provide a link to the Creative Commons licence, and indicate if changes were made. The images or other third party material in this article are included in the article's Creative Commons licence, unless indicated otherwise in a credit line to the material. If material is not included in the article's Creative Commons licence and your intended use is not permitted by statutory regulation or exceeds the permitted use, you will need to obtain permission directly from the copyright holder. To view a copy of this licence, visit http://creativecommons.org/licenses/by/4.0/ The Creative Commons Public Domain Dedication waiver (http://creativecommons.org/publicdomain/zero/1.0/) applies to the data made available in this article, unless otherwise stated in a credit line to the data. 


\begin{abstract}
(Continued from previous page)
Conclusions: We conclude that heat shock-induced cell death is an energy-independent process best matching definition of necrosis. Although the initial steps of this necrotic cell death could be genetically regulated, classifying it as apoptosis or AL-PCD is a terminological misnomer. Our work supports the viewpoint that apoptosis is not conserved across animal and plant kingdoms and demonstrates the importance of focusing on plant-specific aspects of cell death pathways.
\end{abstract}

Keywords: Apoptosis, Apoptosis-like programmed cell death, Ferroptosis, Heat shock, Mitochondrial dysfunction, Necrosis, Plants, Plasma membrane integrity, Protoplast shrinkage, Regulated cell death, Stress

\section{Background}

Upon acute stress, cells might succumb to an accidental necrosis, which is essentially an unregulated collapse of cellular functions. In contrast, regulated cell death (RCD) is a genetically encoded process of cellular suicide, which is built into physiology of a multicellular organism [1]. For example, programmed cell death (PCD), a subcategory of RCD intimately associated with normal development, counteracts cell proliferation by removing aged cells and plays an essential role in morphogenesis by eliminating surplus cells and shaping new structures [2-5]. Other examples of RCD are implicated in stress responses, restricting the spread of pathogens through tissues and confining damage caused by abiotic factors [5-7]. For historical reasons, in plant research field, RCD is typically referred to as PCD. However, to enable accurate comparison of cell death in animal and plant kingdoms, we apply here the more inclusive term RCD to plants as well.

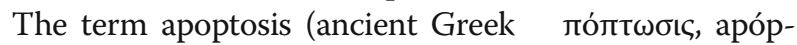
tōsis, "falling off") was coined in the pivotal work of John Kerr and colleagues [8] to name the newly described type of animal RCD after the death of leaves programmed to occur in many plant species at the end of each growth season. Since then, the apoptotic cell death became one of the most studied pathways in animal model systems (for review see [9]). Understanding the plant RCD machinery advanced much slower, and progress in this direction unfortunately suffers from attempts to extrapolate the knowledge obtained on animal models.

The utmost importance of RCD for all multicellular organisms strongly suggests that this process should be evolutionary conserved. Indeed, many examples of RCD in animals and plants share conceptual similarities that can be attributed to the common features of all eukaryotic cells, e.g. dependency on ATP and protein synthesis, regulated proteolysis, and often implication of a careful dismantling of a dying cell so as to protect neighbouring cells from its toxic content $[10,11]$. However, RCD is an integral part of development and a key player in adaptation to environmental conditions, response to stress stimuli and pathogens, all of which would greatly vary depending on the life strategy of an organism. Thus, differences in cell organization, motility, genome maintenance, nutrition, and body plan plasticity between animals and plants [12, 13] could not have been shaped without tailoring their corresponding RCD machineries.

One of the most apparent differences between animals and plants is cell motility. Unlike animal cells, rigid carbohydrate walls of plant cells prevent guided migration within a multicellular organism [14]. This fact alone illustrates the profound differences that can be expected between plant and animal RCD. Namely, due to the cellular immobility, plants lack mechanisms for preventing spread of malignant cells and do not have metastatic cancer. Thus, somatic mutations in plant and animal cells pose fundamentally different level of danger to their organisms, which shaped distinct strategies of the RCD regulation by the DNA damage controlling machinery $[15,16]$. Furthermore, execution of the RCD should also be different, as the cell walls make animal strategies of cellular disassembly not applicable for plant cells. For instance, apoptotic cells undergo fragmentation into smaller apoptotic bodies that can be taken up by phagocytes in a highly regulated fashion involving decoration of the apoptotic bodies with phosphatidylserine [17]. The lack of phagocytes in plants means that apoptotic bodies would remain trapped within the cell wall cage, eventually undergoing decay and spilling toxic contents on the neighbouring cells. Thus, plant RCD should rely on specific regulation and execution mechanisms [11].

Although apoptosis was initially considered a synonym for RCD or PCD, numerous non-apoptotic types of RCD have been discovered in animals in the past two decades $[1,18,19]$, such as paraptosis [20], several forms of regulated necrosis (necroptosis [21], ferroptosis [22], pyroptosis [23]), and others. Since animals possess multiple RCD pathways shaped to best fit the physiology of the organism under varying conditions, it is safe to assume that plant evolution shaped plant-specific RCD mechanisms.

The continuous search for biochemical manifestations of apoptosis in plants thus far has yielded unconvincing results. For instance, plants lack the core apoptotic regulators caspases and B cell lymphoma 2 (Bcl-2) family proteins [24, 25]. Furthermore, although increase in caspase-like proteolytic activity has been detected during plant cell death [26], the analysis of the plant genome 
sequence data demonstrated lack of caspases [27]. It remains to be further determined what subset of plant proteases is responsible for cell death-associated caspase-like activity, what are their substrates, and what is the mechanistic role of limited proteolysis in the activation and execution of RCD (for review see [28]). The closest plant structural homologues of caspases, metacaspases, are indeed implicated in plant RCD [29, 30]; however, their substrate specificity and regulation are profoundly different from caspases [31, 32]. These facts point out the lack of instruments for apoptotic cell death in plants and support the existence of plant-specific RCD mechanisms.

Another example is Bcl-2 family proteins that play either pro- or anti-apoptotic functions in animals by regulating permeabilization of the outer mitochondrial membrane followed by the release of cytochrome $c$ [33]. It has been shown that ectopic expression of animal genes encoding pro- or anti-apoptotic $\mathrm{Bcl}-2$ family members in plants can enhance or suppress cell death, respectively [34, 35]. However, it is not surprising that animal proteins inducing permeabilization of the outer mitochondrial membrane would cause mitochondrial dysfunction eventually leading to cell death in heterologous systems. Furthermore, although interaction of animal anti-apoptotic Bcl-2 protein with as yet to be identified plant protein might indeed decrease plant cell susceptibility to death stimuli, the lack of Bcl-2 genes in plant genomes points out that plant RCD does not rely on activity of these proteins and is thus regulated differently from the apoptotic pathway [36, 37]. Nevertheless, original research and reviews on apoptotic hallmarks in plant cell death are still being published (for recent reviews, see [38-41]), propagating controversial conclusions that require careful consideration.

Apoptotic cell death has typical hallmarks: (i) it is an active, ATP- and caspase-dependent process [42, 43]; (ii) the plasma membrane (PM) integrity is retained throughout the cell death process and phosphatidylserine is exposed on the outer membrane surface as an "eat me" signal for phagocytes [44, 45]; (iii) cell shrinkage (or apoptotic volume decrease, AVD) is followed by chromatin condensation and nuclear segmentation $[1,18$, 46]; (iv) PM blebbing results in cell fragmentation into apoptotic bodies $[10,47]$ and their subsequent phagocytosis [17].

The term "apoptosis-like PCD" (AL-PCD) was coined due to the reported morphological and biochemical similarities between animal apoptosis and stressassociated plant cell death, primarily AVD-like protoplast shrinkage, but also $\mathrm{Ca}^{2+}$ and ATP dependency, maintenance of PM integrity, and involvement of caspase-like activity [48-51]. However, studies reporting on such similarities contain a number of controversies that need to be addressed before drawing conclusions (Table 1).

Plant AL-PCD is commonly induced by an acute heat stress, e.g. a pulse heat shock (HS) at $40-55^{\circ} \mathrm{C}$ (Table 1 $[49,71-74])$. However, such temperatures are on the edge of the physiologically relevant range and could likely cause acute damage resulting in accidental necrotic cell death, rather than trigger a programmed response. Unlike apoptosis, accidental necrotic cell death is associated with a drop of cellular ATP content, occurs independently of caspases, displays early PM permeabilization leading to the leakage of the cellular content into the extracellular environment, and is considered to be generally unprogrammed process under conditions when RCD fails $[75,76]$.

To reconcile the reported features of plant AL-PCD with the confirmed lack of the key components of the apoptotic machinery and the general ineptness of the apoptotic cell death strategy in the context of a plant organism, we systematically analysed cell death hallmarks occurring under conditions reported to trigger AL-PCD $\left(40-55^{\circ} \mathrm{C} \mathrm{HS}\right)$ and necrosis $\left(85^{\circ} \mathrm{C} \mathrm{HS}\right)[61,70]$. We took special care to include appropriate controls for potential technical pitfalls and performed most of the experiments using highly reliable Bright Yellow-2 (BY-2) tobacco cell culture, the so-called "plant HeLa" model system [77] often implemented for plant RCD studies (Table 1 [49, $78]$ ). We show that while protoplast shrinkage during $55^{\circ} \mathrm{C}$ HS-induced cell death superficially resembles AVD, it is independent of ATP or $\mathrm{Ca}^{2+}$ and coincides with instant and irreversible loss of PM integrity. This cell death lacks other key apoptotic features, such as PM blebbing, nuclear segmentation, and formation of apoptotic bodies. The side-by-side comparison of cell death triggered by $55^{\circ} \mathrm{C}$ and $85^{\circ} \mathrm{C}$ revealed remarkable similarities to necrosis in both cases. Importantly, the abovedescribed hallmarks of accidental necrosis would also match features of regulated necrotic cell death [19]. However, this study did not aim at determining whether necrosis induced by $\mathrm{HS}$ is accidental or regulated process. Furthermore, we demonstrate that the previously reported striking morphological difference between cell deaths triggered by $55^{\circ} \mathrm{C}$ and $85^{\circ} \mathrm{C}$, i.e. the lack of protoplast shrinkage in cells exposed to $85^{\circ} \mathrm{C}$, is merely a consequence of the fixative effect of the high temperature on cellular content. We conclude that cell death in the model system typically used to study ALPCD is indistinguishable from necrosis.

\section{Results and discussion}

\section{HS-induced plant cell death is morphologically distinct} from apoptosis

One of the earliest hallmarks of apoptosis is AVD [79, 80], followed by blebbing of the PM, nuclear segmentation and finally fragmentation of the cell into apoptotic 
Table 1 A brief account of major hallmarks of animal apoptosis analysed in plant models for AL-PCD

\begin{tabular}{|c|c|}
\hline $\begin{array}{l}\text { Hallmark of } \\
\text { apoptosis }\end{array}$ & Experimental model/detection method \\
\hline Impermeable PM & $\begin{array}{l}52^{\circ} \mathrm{C} \text { HS of Arabidopsis thaliana cell culture/ } \\
\text { Trypan blue staining } \\
\text { Victorin-treated oat (Avena sativa) seedlings/ } \\
\text { TMRM staining }\end{array}$ \\
\hline ATP requirement & $\begin{array}{l}\text { Benzyladenosine-treated tobacco (Nicotiana } \\
\text { tabacum) BY-2 cell culture/ATP bioluminiscence } \\
\text { assay } \\
\text { Ceramide-treated rice (Oryza sativa) protoplasts/ } \\
\text { ATP bioluminiscence assay }\end{array}$ \\
\hline $\begin{array}{l}\text { Cytochrome c } \\
\text { release from } \\
\text { mitochondria }\end{array}$ & $\begin{array}{l}55^{\circ} \mathrm{C} \mathrm{HS} \text { of cucumber (Cucumis sativus) } \\
\text { cotyledons/Western blotting } \\
55^{\circ} \mathrm{C} \text { HS of BY-2 cell culture/Western blotting }\end{array}$ \\
\hline Activity of caspases & $\begin{array}{l}\text { Salt-stressed Thellungiella halophila cell culture/ } \\
\text { Caspase substrates and inhibitors } \\
45^{\circ} \mathrm{C} \text { HS- or victorin-treated oat (Avena sativa) } \\
\text { seedlings/Caspase substrates and inhibitors }\end{array}$ \\
\hline
\end{tabular}

DNA

fragmentation

Sanguinarine-treated onion (Allium cepa) roots/ TUNEL staining

Arabidopsis protoplasts subjected to ultravioletC/TUNEL staining

PM blebbing

$55^{\circ} \mathrm{C}$ HS of carrot (Daucus carota) cells cultured

Microspore degeneration in the female flowers of Actinidia deliciosa/TEM

Formation of apoptotic bodies

$52^{\circ} \mathrm{C} \mathrm{HS}$ of tobacco (N. tabacum) cell culture/ TUNEL staining

Mycotoxin fumonisin B1-treated tomato (Solanum lycopersicum) seedlings/PI and TUNEL staining

Phosphatidylserine Chlamydomonas reinhardtii cells subjected to exposure ultraviolet-C/Annexin-V binding assay, fluoresat low density/TEM

\section{Reference Controversy}

[51]

[52] cent microscopy

Campothecin-treated tobacco (Nicotiana plumbaginifolia) protoplasts/Annexin-V binding assay, flow cytometry characteristic for both apoptosis and necrosis in animal models [65] was detected in both studies.

DNA fragmentation is not specific to apoptosis and can occur under various types of cell death [11].

No evidence for impermeability of PM and bleb formation outwards on the cell surface [45] in both studies.

Phosphatidylserine exposure during apoptosis constitutes "eat me" signal for phagocytes which are absent in plants. Furthermore, phosphatidylserine exposure is not exclusive to apoptosis and also occurs in regulated forms of necrosis [68].
At least half of the cells with shrunken protoplasts were Trypan blue-positive already $30 \mathrm{~min}$ post-HS. Therefore, PM integrity is not a reliable hallmark for this cell death. TMRM is a cell permeant mitochondrial dye and cannot be used for the analysis of PM integrity.

Drop of ATP detected in both studies, whereas apoptosis is ATPdependent process.

Cytochrome $c$ translocation during apoptosis is required for apoptosome-mediated activation of caspases [56]. The mechanistic role of cytosolic cytochrome $c$ in plant cell death remains unknown.

Increased DEVDase activity detected; protease(s) responsible for the activity is unknown.

Increased DEVDase and VADase activities caused by subtilisin-like serine proteases.

In both cases, biological targets of the proteases with caspaselike activities are unknown undermining conclusions on similarities with caspase-dependent signaling and execution of apoptosis.

In addition to the above-listed apoptotic hallmarks, most of those studies reported protoplast shrinkage. Since this is not a review article, we are not providing an exhausting list of relevant publications, but only representative studies illustrating controversies within the field of plant AL-PCD. More comprehensive account of previous works describing the occurrence of AL-PCD in plants can be found elsewhere [38-41, 69, 70]. HS, heat shock; PI, propidium iodide; PM, plasma membrane; TEM, transmission electron microscopy; TMRM, tetramethylrhodamine methyl ester; TUNEL, terminal deoxynucleotidyl transferase-mediated dUTP nick-end labelling.

bodies [17]. Since the ultimate goal of such cell dismantling is removal of the dying cell by phagocytes, the PM of the apoptotic cell should remain intact throughout the whole process, preventing spillage of the dying cell content. It is fairly obvious that formation of apoptotic bodies during plant cell death would serve no purpose, as plants lack phagocytes and a dead plant cell remains to be incapsulated within a rigid cell wall $[25,81]$. However, death of plant cells caused by abiotic or biotic stress is accompanied by rupture of PM and/or vacuolar membrane, tonoplast, causing severe damage to the endomembrane systems and irreversible detachment of the PM from cell wall which is often referred to as the protoplast shrinkage $[11,82]$. This phenomenon has been repeatedly confused with AVD, PM blebbing and formation of apoptotic bodies, and thus exploited to support existence of AL-PCD in plants [38, 39].

To examine AVD, PM blebbing, nuclear segmentation and cellular fragmentation in plants, we analysed morphology of tobacco BY-2 cells under HS conditions that were previously described to induce AL-PCD [48, 51]. Cell culture was stained with a noncell-permeable Sytox Orange (SO) nucleic acid dye to visualize cells with 
compromised PM integrity and with the styryl dye FM464 to visualize cell membranes and then subjected to a pulse $\mathrm{HS}$ at $55^{\circ} \mathrm{C}$ (Additional file 1: Video S1).

Only SO-positive cells exhibited protoplast shrinkage, strongly indicating correlation between cell volume decrease and PM permeabilization (Fig. 1a). Notably, the treated cells became SO-positive at the earliest checked time point, i.e. within $10 \mathrm{~min}$ of the $\mathrm{HS}$ indicating rapid $\mathrm{PM}$ permeabilization. One prominent feature of SOpositive cells was formation of vesicle-like structures at the inner side of the PM (Fig. 1a, b). Such morphology is inconsistent with AVD and blebbing, which require intact PM; furthermore, apoptotic PM blebs form outwards on the cell surface [45].

The PM and shrunken protoplast were additionally imaged in the time interval from $15 \mathrm{~min}$ to $72 \mathrm{~h}$ after the pulse HS (Additional file 2: Figure S1). Nevertheless, we failed to detect PM blebbing or protoplast fragmentation into discrete bodies at any time point. Furthermore, although we did observe moderate nuclear condensation upon HS, it was not followed by segmentation of the nucleus (Fig. 1c, d). In summary, the gross morphological changes of cells undergoing HS-induced cell death do not resemble apoptosis.

\section{PM integrity is irreversibly compromised during or shortly after pulse HS}

Intact PM is a pivotal hallmark of apoptosis [10]. However, SO staining described above suggested permeabilization of PM in most BY-2 cells already within 10 min of the HS. To investigate dynamics of the PM permeabilization, we analysed cellular content leakage after two types of $\mathrm{HS}$, at $55^{\circ} \mathrm{C}$ or $85^{\circ} \mathrm{C}$ which were reported to induce AL-PCD or necrosis, respectively [61, 70]. The leakage of cellular content was assessed using a fluorescein diacetate (FDA)-based fluorochromatic assay [83]. In brief, the non-fluorescent FDA molecules can passively diffuse into the living cells where their acetate groups are cleaved off by esterases. The resulting fluorescein molecules have poor membrane permeability and are retained in cells with an intact PM, but are released into extracellular space upon PM permeabilization.

We imaged BY-2 cells loaded with FDA prior to the pulse HS at $55^{\circ} \mathrm{C}$ or $85^{\circ} \mathrm{C}$ (Fig. 2a). Both types of HS caused rapid (within $10 \mathrm{~min}$ ) leakage of the dye into the extracellular space (Fig. 2a). We measured the amount of fluorescein accumulated in the extracellular space immediately after the HS and found that the rate of cellular content leakage in HS-treated cells was comparable to that occurring after severe disruption of plant cells caused by freeze-thaw in liquid nitrogen (Fig. 2b).

To determine whether PM permeabilization was transient or permanent, we added SO and FM4-64 stains to the cell cultures either before or $30 \mathrm{~min}$ after HS. We speculated that if PM permeabilization upon HS was transient, cultures stained after HS would show a significantly lower frequency of SO staining as compared to cells stained before HS. However, SO staining before and after $55^{\circ} \mathrm{C}$ or $85^{\circ} \mathrm{C}$ HS showed no differences in the proportion of SO-positive cells (Fig. 2c, d), indicating that both treatments caused irreversible rapid permeabilization of PM typical for necrosis [10, 11, 84].

The protoplast shrinkage during HS-induced cell death is ATP- and $\mathrm{Ca}^{2+}$-independent

Dismantling of the apoptotic cells is ATP-dependent $[42,85]$. Yet, loss of the PM integrity would lead to rapid depletion of intracellular ATP, rendering all energydependent processes defunct. To examine whether the HS-induced cell death requires ATP, we first imaged mitochondria after $55^{\circ} \mathrm{C}$ and $85^{\circ} \mathrm{C}$ HS. Already at the earliest checked time points 4-10 min after HS, under both temperatures, mitochondrial dye MitoTracker localized to aberrant structures similar to those observed after treatment with mitochondrial uncoupler and ATP synthesis inhibitor, protonophore carbonyl cyanide $\mathrm{m}$ chlorophenylhydrazone (CCCP) [86], indicating disruption of mitochondrial membrane potential (MMP; Fig. 3a). Furthermore, intracellular ATP content dropped dramatically after both HS treatments (Fig. 3b), most probably due to dissipation of the MMP and leakage of cytoplasmic content through the permeabilized PM.

In addition to ATP depletion, PM permeabilization would also cause entry of $\mathrm{Ca}^{2+}$ into the cells, potentially followed by its accumulation in mitochondria. MMPdriven accumulation of $\mathrm{Ca}^{2+}$ can trigger mitochondrial permeability transition (MPT) due to the opening of a nonspecific pore (mitochondrial permeability transition pore, MPTP) [87], which will cause arrest of ATP synthesis and production of reactive oxygen species ultimately resulting in necrotic cell death [88]. Although HSinduced plant cell death was previously suggested to be $\mathrm{a} \mathrm{Ca}^{2+}$-dependent process [51], those experiments lacked controls for mitochondrial phenotype, respiration or ATP production.

To test whether MPT plays a role in the observed mitochondrial phenotype, experiments were performed in the presence of cyclosporin A (CsA), an inhibitor of MPTP opening, or the $\mathrm{Ca}^{2+}$ chelator ethylene glycol-bis (2-aminoethylether)-N, $\mathrm{N} \mathrm{N}^{\prime}, \mathrm{N}^{\prime}$-tetraacetic acid (EGTA). Neither CsA nor EGTA could alleviate the mitochondrial phenotype in cells subjected to the HS (Fig. 3c, d), indicating that mitochondrial malfunction was caused by the direct loss of the mitochondrial membrane integrity during the HS, independently on PM permeabilization.

Next, we examined the importance of intracellular ATP for the AVD-like protoplast shrinkage. We found 


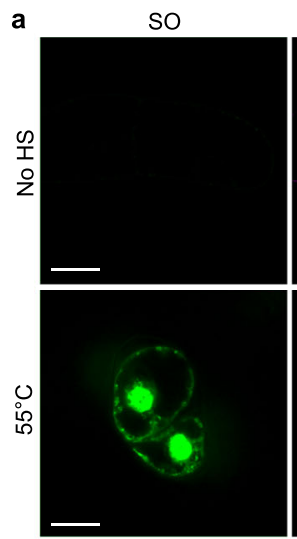

c

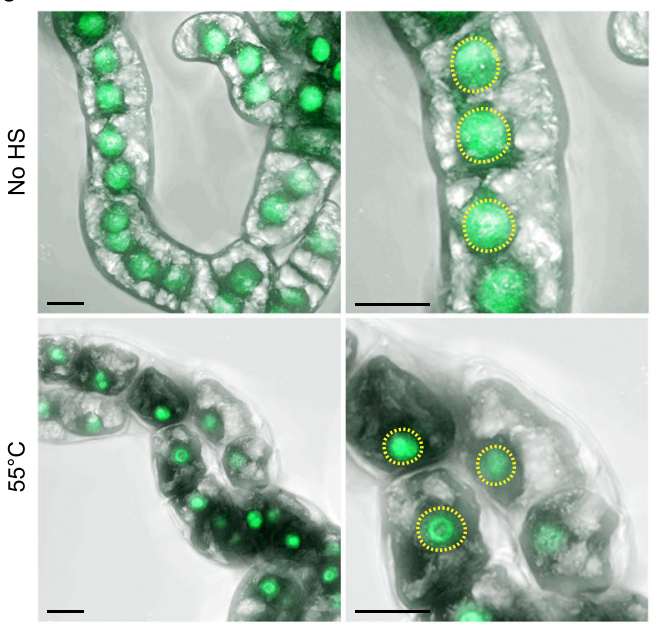

DIC
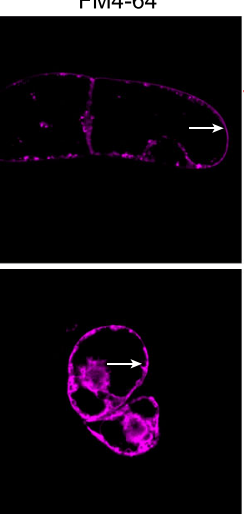

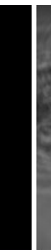

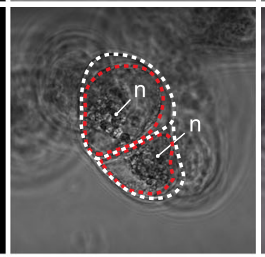

d SO + FM4-64 + DIC
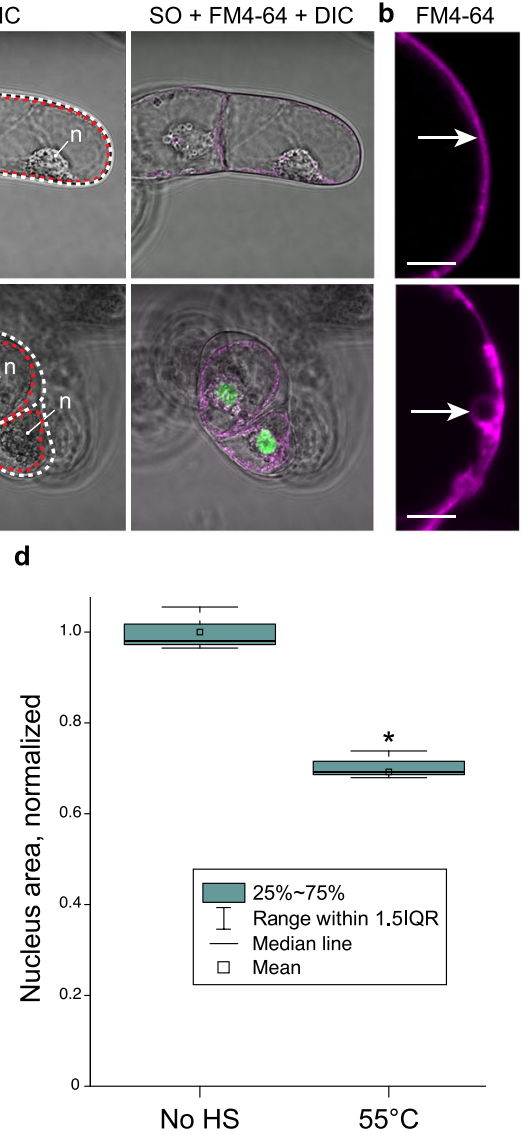

Fig. 1 Gross morphological changes in HS-treated plant cells do not match hallmarks of apoptosis. a FM4-64 and SO dyes were used to visualize all cells and cells with permeabilized PM, respectively. BY-2 cells were imaged under control conditions (No HS) or after a 10-min $\mathrm{HS}$ at $55^{\circ} \mathrm{C}$ and were stained according to protocols i and ii, respectively (see "Sytox Orange and FM4-64 staining"). Scanning was performed within $1 \mathrm{~h}$ post-HS. The arrows indicate PM; note the PM (red dotted line) being tightly pressed to the cell wall (white dotted line) under control conditions and detached under stress conditions. $\mathbf{b}$ Higher magnification of the areas indicated with arrows in $\mathbf{a}$. c BY-2 cells expressing green fluorescent protein (GFP) fused to nuclear localization signal (NLS) were subjected to the same treatments as in a. Images represent maximum intensity projections of z-stack scans acquired $6 \mathrm{~h}$ post-HS. d Quantification of nuclear area in samples shown in c. Data from three independent experiments, with $\geq 142$ cells counted per treatment. Student's $t$ test, ${ }^{*} p<0.005$. DIC, differential interference contrast microscopy. n, nucleus. IQR, interquartile range. Scale bars, $20 \mu \mathrm{m}(\mathbf{a}$, c) or $5 \mu \mathrm{m}(\mathbf{b})$

that pre-treatment of the cell cultures with CCCP prior to HS had no effect on the protoplast shrinkage (Additional file 2: Figure S2), demonstrating that the protoplast shrinkage does not require ATP. Time-resolved quantitative analysis of cell death (frequency of SOpositive cells) and protoplast shrinkage upon HS of cells with normal or uncoupled mitochondria revealed that both parameters were independent of the mitochondrial bioenergetic function (Fig. 3e, f). Pre-treatment with CsA or EGTA prior to HS did not alleviate the cell death rate either (Fig. 3g, h; Additional file 2: Figure S2).

The discrepancies between our observations and the previous studies could be caused by technical issues, primarily precision of the temperature measurement during HS. To examine this possibility, we compared frequency and phenotype of cell death after treatment at 40, 45, 50 and $55^{\circ} \mathrm{C}$. Although cell viability was inversely proportional to the temperature, the morphology of dead cells in all cases was identical to that observed at $55^{\circ} \mathrm{C} \mathrm{(Fig.} \mathrm{4).}$ Pre-treatment of cells with CCCP confirmed that at any of the checked temperatures the rate of cell death did not depend on mitochondrial activity (Fig. 4).

A recent study [89] proposed that $\mathrm{HS}$ at $55^{\circ} \mathrm{C}$ caused ferroptosis in A. thaliana root hair cells. Therefore, we examined whether the cell death we observed in BY-2 cells under the same stress conditions could be classified as a ferroptosis. For this, BY-2 cells were treated with a ferroptosis inhibitor, Ferrostatin-1 (Fer-1), prior to $\mathrm{HS}$ at $55^{\circ} \mathrm{C}$ and cell death rate was measured during $24 \mathrm{~h}$ after the stress. Treatment with Fer-1 did not alleviate the cell 
a

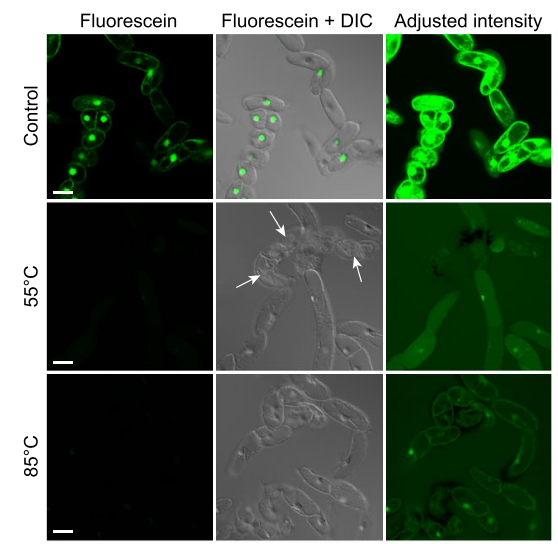

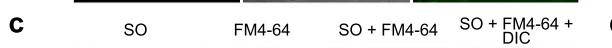
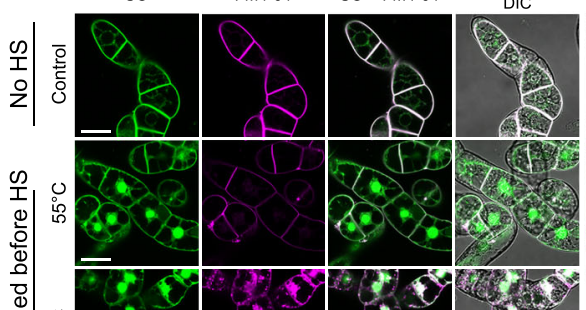

के
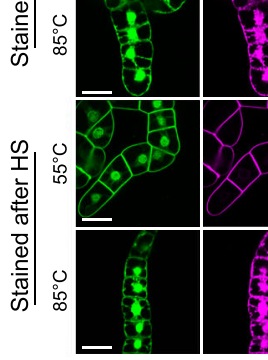

b

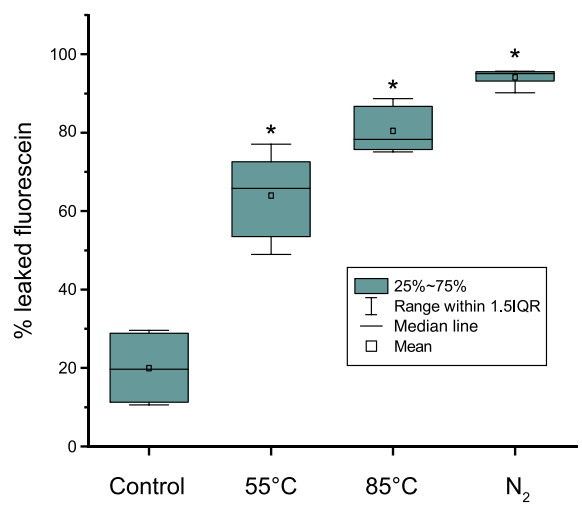

d

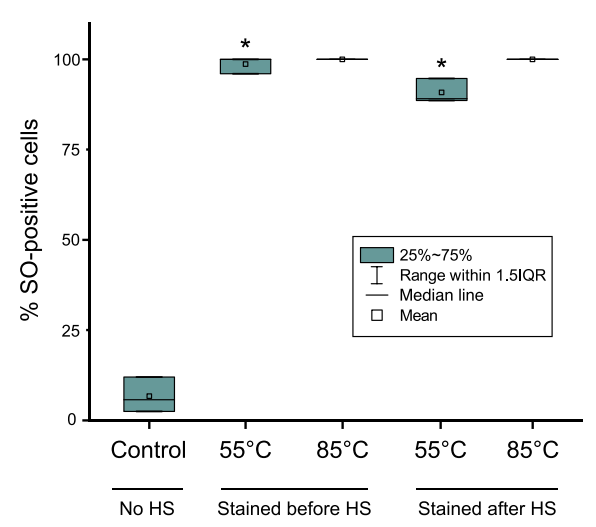

Fig. 2 Both $55^{\circ} \mathrm{C}$ and $85^{\circ} \mathrm{C} \mathrm{HS}$ cause instant and irreversible PM permeabilization. a Green fluorescence in the BY-2 cells loaded with FDA. Fluorescein leaks into extracellular space within 10 min after $\mathrm{HS}$ at either $55^{\circ} \mathrm{C}$ or $85^{\circ} \mathrm{C}$. Arrows indicate shrunken protoplasts in $55^{\circ} \mathrm{C} \mathrm{HS}$-treated cells. b Similar fraction of fluorescein leaks out of cells after 10 min of $55^{\circ} \mathrm{C}, 85^{\circ} \mathrm{C}$ or liquid nitrogen $\left(\mathrm{N}_{2}\right)$ treatment. c BY-2 cells stained with SO and FM4-64 to assess whether disruption of the PM integrity after pulse HS is transient or irreversible. Staining was performed for no HS, before HS or after HS treatments according to protocols i, ii and iii, respectively (see "Sytox Orange and FM4-64 staining"). The cultures were imaged within $1 \mathrm{~h}$ following HS. $\mathbf{d}$ Frequency of the SO-positive cells in the cultures shown in c. DIC, differential interference contrast microscopy. IQR, interquartile range. Scale bars in a and c, $50 \mu \mathrm{m}$. b Representative data from one out of three independent experiments. $\mathbf{d}$ Data from three independent experiments, with $\geq 115$ cells counted per treatment. $\mathbf{b}$, $\mathbf{d}$ One-way ANOVA with Dunnet's test; ${ }^{*} p<0.005$

death (Fig. 5a, b; data is shown for the first $12 \mathrm{~h}$ after HS). Furthermore, two independent experiments replicating conditions that were reported to induce ferroptosis in Arabidopsis root hair cells [89] did not confirm such type of cell death (Fig. 5c). Taken together, our results reject the notion that HS-induced cell death is a programmed process. On the contrary, they demonstrate that HS triggers rapid destruction of cellular components and passive decay of plant cells resembling accidental necrosis.

\section{Necrotic deaths caused by $55^{\circ} \mathrm{C}$ or $85^{\circ} \mathrm{C}$ display different cell morphologies due to a fixating effect of higher temperature}

The lack of protoplast shrinkage during cell death induced by $85^{\circ} \mathrm{C}$ was used to classify it as necrosis $[61,70]$.
However, both $55^{\circ} \mathrm{C}$ and $85^{\circ} \mathrm{C}$ HS trigger instant and irreversible permeabilization of the PM, MMP dissipation, and drop in intracellular ATP content, which are hallmarks of necrosis [84]. Plausibly, morphological differences between necrotic cell deaths triggered by $55^{\circ} \mathrm{C}$ and $85^{\circ} \mathrm{C}$ could be explained by rapid protein denaturation occurring at $85^{\circ} \mathrm{C}$ that would crosslink cellular components. Such "fixation" would prevent protoplast shrinkage. Consistent with this suggestion, high-temperature cell fixation protocols have been used as an alternative to chemical fixation [90].

To test whether $85^{\circ} \mathrm{C} \mathrm{HS}$ acts as a fixative, we induced protoplast retraction from the cell wall by exposing stressed cell cultures to hypertonic conditions at 500 mM D-mannitol (Fig. 6a). The high osmotic pressure of 


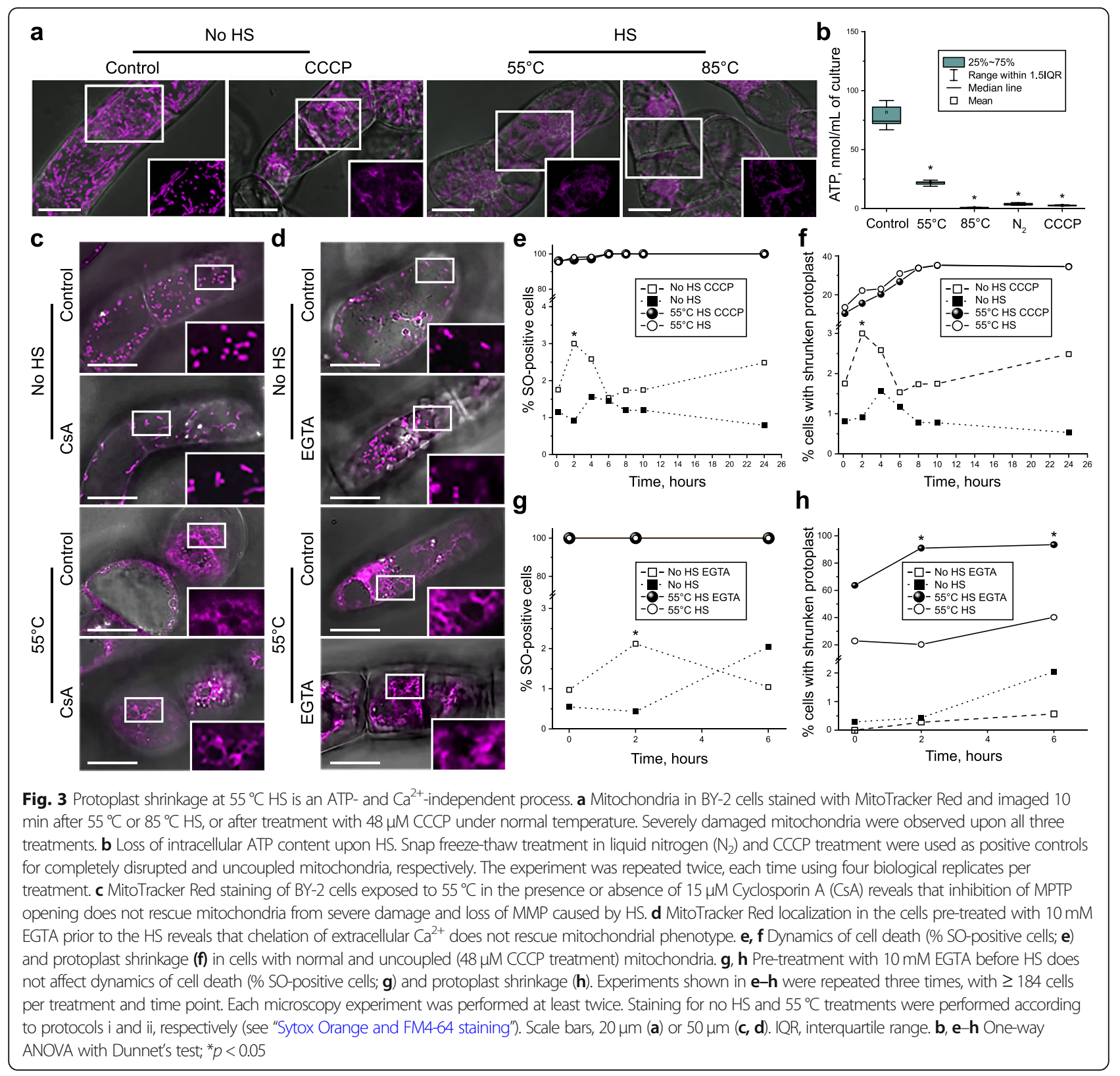

the medium would induce dehydration and protoplast shrinkage in the non-fixed cells. As expected, the living cells treated with D-mannitol underwent typical plasmolysis manifested by reversible protoplast detachment from the cell wall. Cells exposed to $55^{\circ} \mathrm{C}$ displayed irreversible protoplast shrinkage phenotype both with and without D-mannitol treatment. However, although cells treated at $85^{\circ} \mathrm{C}$ HS exhibited visible signs of dehydration in the hypertonic solution, protoplasts of virtually all cells remained attached to the cell wall. Quantitative analysis revealed no significant changes in the protoplast area of cells treated at $85^{\circ} \mathrm{C}$ HS under normal or high osmotic pressure (Fig. 6b). These data provide compelling evidence that the fixing effect of $85^{\circ} \mathrm{C}$ HS prevents protoplast shrinkage. Thus, distinct phenotypes of cell deaths induced by $\mathrm{HS}$ at $55^{\circ} \mathrm{C}$ and $85^{\circ} \mathrm{C}$ do not reflect differences in the cell death execution mechanism.

\section{Conclusions}

This study draws attention to the existing disagreements in plant cell death research community about the existence of apoptosis in plants and emphasizes the need for in-depth investigation of plant-specific RCD features, which will hopefully boost our understanding of the evolution of eukaryotic cell death machinery. Research on plant cell death greatly benefits from the wealth of knowledge obtained on animal RCD, but also frequently suffers from the lingering superficial comparisons between both 

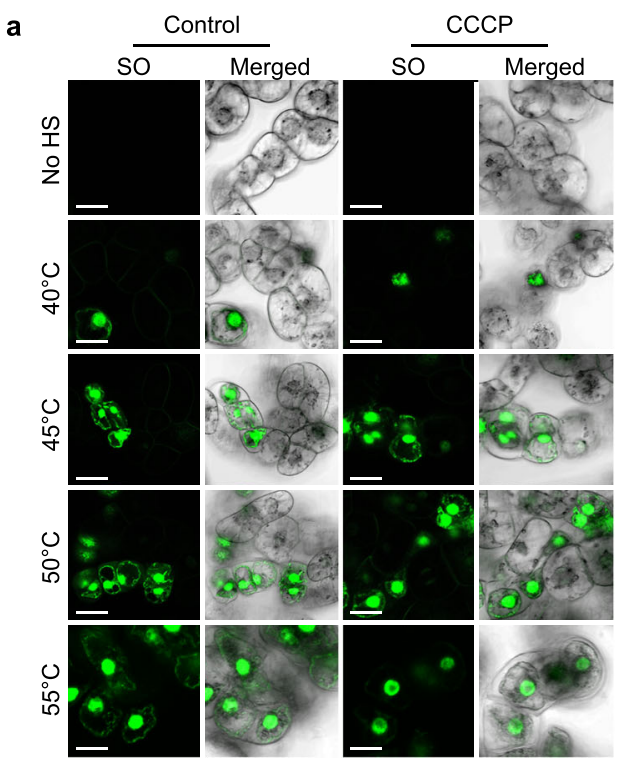

6 hours post-HS

b

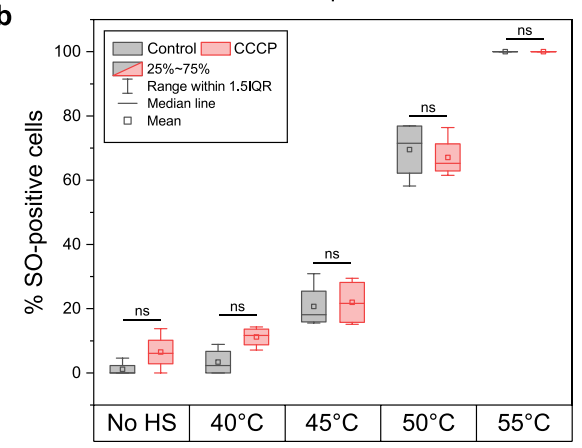

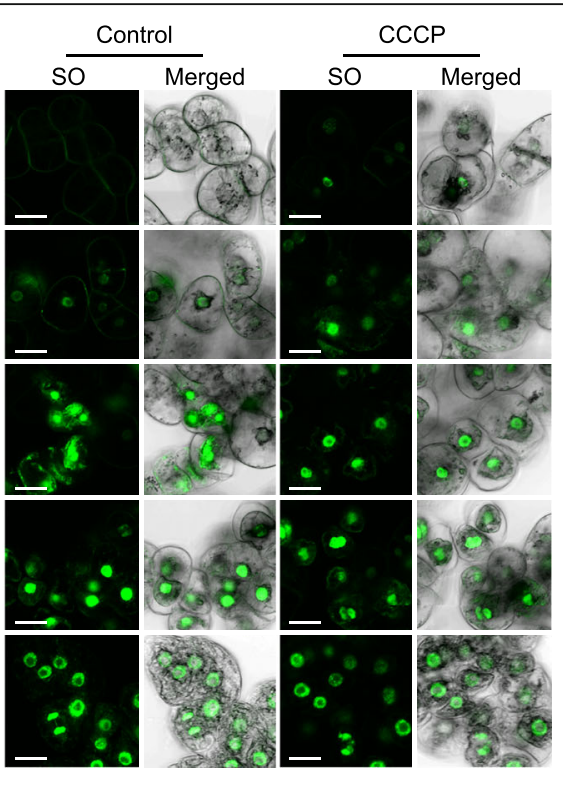

24 hours post-HS

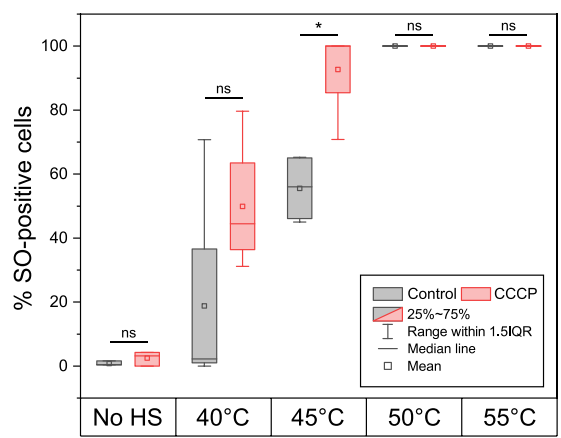

Fig. $4 \mathrm{HS}$ at the temperature range $40-55^{\circ} \mathrm{C}$ induces ATP- independent cell death. a SO staining of BY-2 cells heat-shocked for 10 min at 40 , 45,50 or $55^{\circ} \mathrm{C}$ and imaged after 6 or $24 \mathrm{~h}$. b Quantification of cell death (\% SO-positive cells) in the samples showed that pre-treatment with CCCP provided no protection against cell death and protoplast shrinkage at any of the tested HS temperatures. On the contrary, after prolonged exposure (24 h), CCCP appeared to decrease HS tolerance of plant cells. Staining was performed for no HS and HS treatments according to protocols i and ii, respectively (see "Sytox Orange and FM4-64 staining"). IQR, interquartile range. Experiments were repeated three times, with $\geq 134$ cells per treatment and time point. The data was subjected to one-way ANOVA with Bonferroni correction. ${ }^{*} p<0.05$, ns, non-significant. Scale bars, $20 \mu m$

systems as exemplified in Table 1. Extrapolating detailed knowledge about animal RCD onto plant processes poses a tempting shortcut to a seemingly meaningful interpretation of fragmented data available for plant model systems. Albeit such comparisons can be helpful to promote a new line of investigation, caution should be exercised to ensure that they provide a functional insight and do not lead to a logical dead-end, as it happened with the reports on formation of apoptotic bodies in plants.

An interesting illustrative example of such cautious comparison are the recent works revealing similarities in the complex formation by Nod-like receptor (NLR) proteins involved in plant and animal innate immune responses and cell death regulation [91-93]. These studies showed that resistosome complexes formed by plant NLRs structurally resemble the inflammasome, complex of animal NLRs assembled during immune response and even apoptosome complex formed by the Apaf-1 protein during apoptosis $[56,94,95]$. These complexes share a multimeric wheel-like shape; furthermore, both plant resistosomes and animal inflammasomes are proposed to trigger cell death mediated by formation of pores in the PM. However, this exciting resemblance is at the same time juxtaposed by a fundamental difference in the mechanisms of action for these complexes in plant and animal cell deaths. While plant resistosomes are proposed to directly form pores in the PM [95], the animal inflammosome and apopotosome complexes evolved to work as platforms for activation of caspase cascades in the cytoplasm $[56,94]$.

Results of our current work schematically summarized in Fig. 7 indicate that morphological and biochemical characteristics of plant HS-induced cell death termed in the literature AL-PCD de facto fit the definition of necrosis. Here we exampled a detailed analysis of only one 

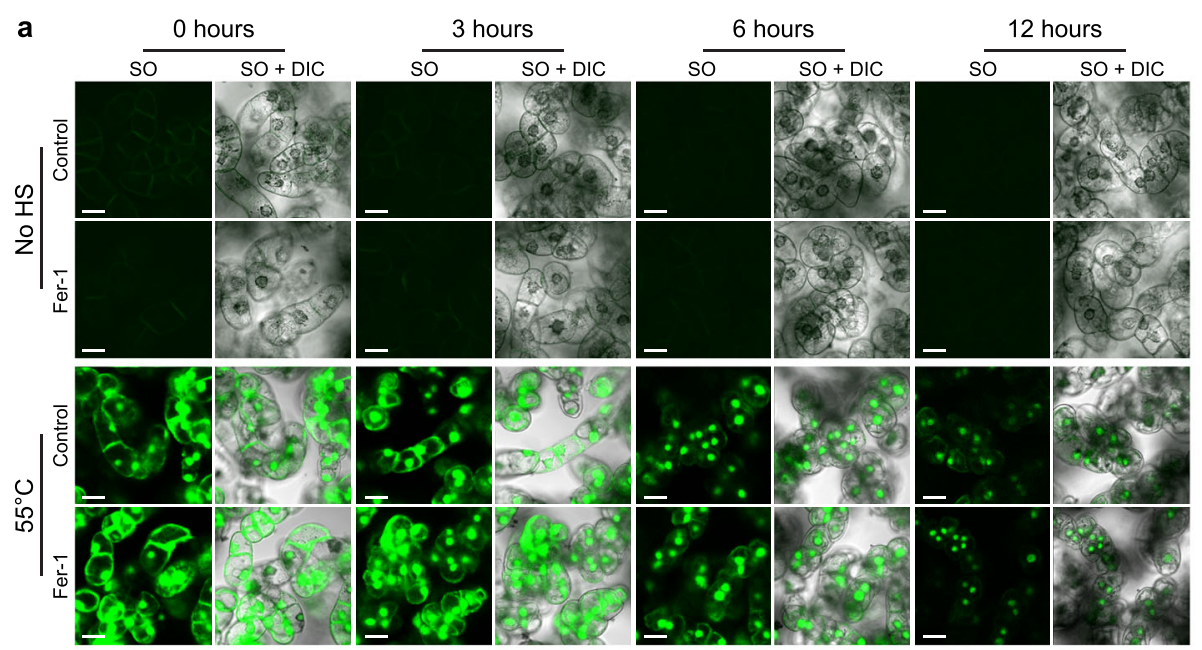

b
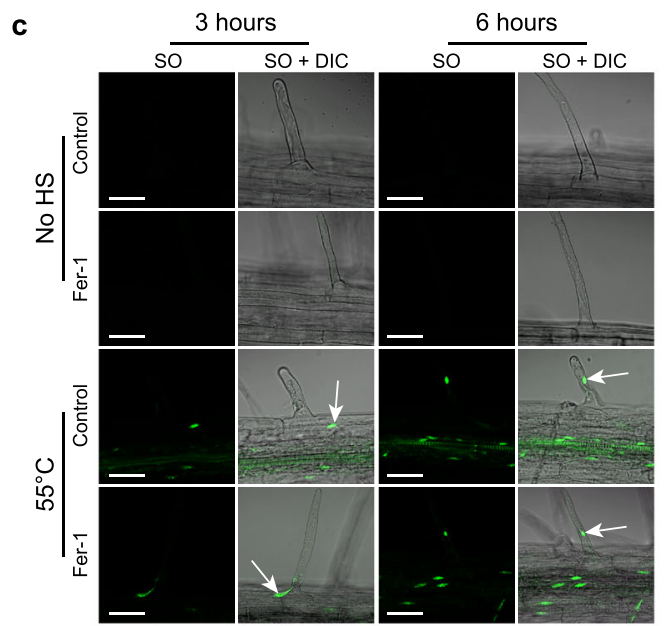

Fig. $5 \mathrm{HS}$-induced cell death response is not ferroptosis. a SO staining of BY-2 cell cultures demonstrates that pre-treatment with $1 \mu \mathrm{M}$ Fer- 1 does not affect $\mathrm{HS}$-induced cell death. Staining for no $\mathrm{HS}$ and $55^{\circ} \mathrm{C}$ treatments was performed according to protocols i and iii, respectively (see "Sytox Orange and FM4-64 staining"). b Quantification of cell death frequency in the samples illustrated in $\mathbf{a}$. The chart shows representative results of three independent experiments, each including $\geq 280$ cells per treatment and time point. c Pre-treatment with Fer-1 does not alleviate the HS-induced death of Arabidopsis thaliana root hair cells. Arrows indicate SO-positive nuclei. Three independent experiments demonstrated the same results. No quantification was performed in these experiments, since all cells were SO-positive. DIC, differential interference contrast. Scale bars, $20 \mu \mathrm{m}$

typical model for plant AL-PCD. Although we cannot rule out that other stimuli could trigger RCD with apoptotic features, this scenario is unlikely due to the lack of the core apoptotic machinery in plants and general pointlessness of apoptosis relying on clean up by mobile cells in the context of plant biology. The set of assays described here can be easily implemented for other plant model systems used for the investigation of cell death with apoptosis-like features (Table 1 [74, 96-106]) and will hopefully provide insights for still existing uncertainties.

\section{Methods}

\section{Plant material and growth conditions}

BY-2 cell cultures [77] were grown at $25^{\circ} \mathrm{C}$ (unless stated otherwise), $120 \mathrm{rpm}$, in the darkness. Cells were subcultured every 7 days to the standard Murashige and Skoog (MS) medium supplemented with vitamins

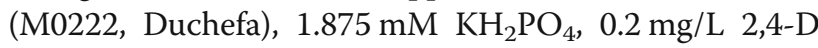
and $3 \%(\mathrm{w} / \mathrm{v})$ sucrose, at $\mathrm{pH}$ 5.6.

For growing Arabidopsis thaliana seedlings, Col-0 seeds were sterilized for $30 \mathrm{~min}$ using a $2.7 \mathrm{~g} / \mathrm{L}$ sodium hypochlorite solution (Klorin, Colgate Palmolive) with $0.05 \%$ (v/ v) Tween 20. The seeds were then rinsed three times with filter-sterilized Milli-Q water prior to being plated on solidified medium. The MS medium was brought to $\mathrm{pH} 5.8$ with $1 \mathrm{M} \mathrm{KOH}$ prior to autoclaving and contained half-strength MS salts and vitamins (M0222, Duchefa), 1\% (w/v) sucrose, $10 \mathrm{mM}$ MES and 0.8\% (w/v) plant agar (P1001, Duchefa). The plates were incubated vertically with cycles of $16 \mathrm{~h}$ of $150 \mu \mathrm{E} \mathrm{m}^{-2} \mathrm{~s}^{-1}$ light at $22^{\circ} \mathrm{C} / 8 \mathrm{~h}$ of dark at $20^{\circ} \mathrm{C}$. 

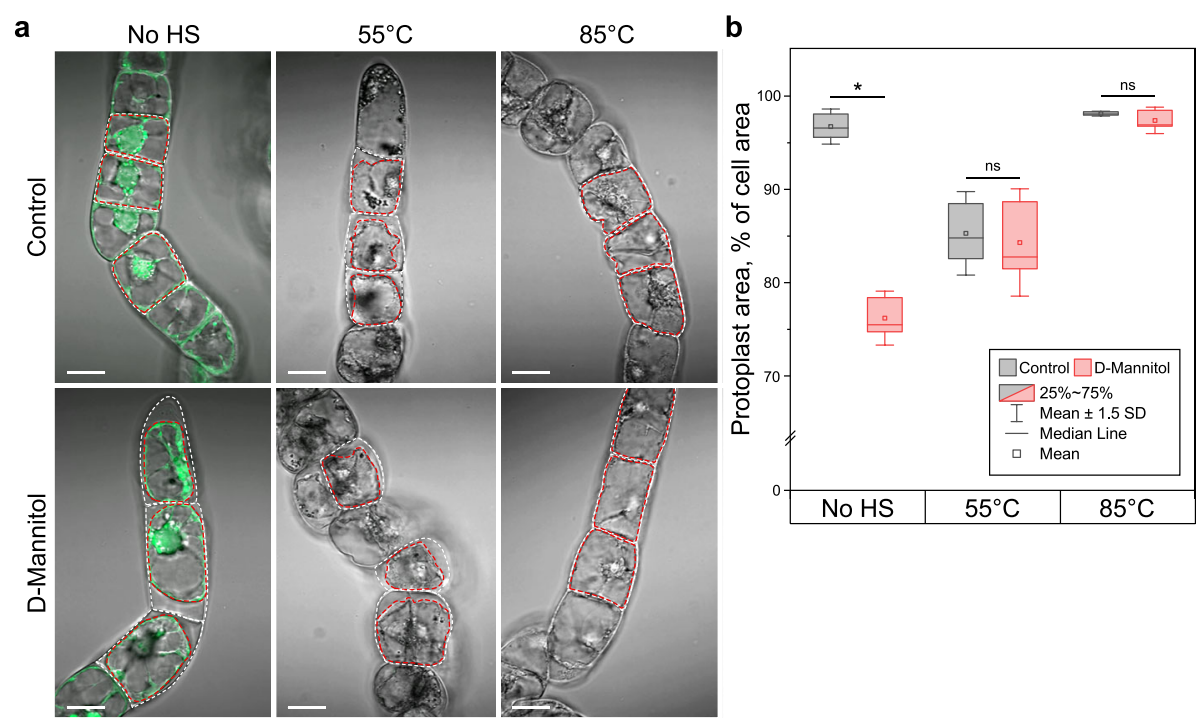

Fig. $685^{\circ} \mathrm{C} \mathrm{HS}$ prevents protoplast shrinkage in necrotic cells by fixing cellular content. a Cells stained with FDA were exposed to $55^{\circ} \mathrm{C}$ or $85^{\circ} \mathrm{C}$ and mounted in the normal growth medium or hypertonic medium supplemented with $500 \mathrm{mM}$ D-mannitol. As expected, hypertonic medium induced plasmolysis in the non-stressed cells (No HS) and had no effect on protoplasts shrunken after $55^{\circ} \mathrm{C} \mathrm{HS}$. Importantly, high osmotic pressure failed to induce protoplast shrinkage in cells exposed to $85^{\circ} \mathrm{C} \mathrm{HS}$, thus confirming that cells were fixed by the high-temperature treatment. $\mathbf{b}$ The extent of protoplast shrinkage upon HS followed by increased osmotic pressure was quantified as the percentage of the cell area (outlined by the white dotted line in a) occupied by the protoplast area (outlined by the red dotted line in a). Student's $t$ test, $n=3$ replicates (each replicate representing $\geq 34$ cells), ${ }^{*} p<0.0001$, ns, non-significant. IQR, interquartile range. Scale bars, $20 \mu \mathrm{m}$

\section{Fluorescein leakage assay (fluorochromatic assay)}

Cells were stained with $4 \mu \mathrm{g} / \mathrm{mL}$ FDA in the culture medium for $10 \mathrm{~min}$ at room temperature. Half a millilitre aliquots of the stained cell culture were then transferred into 2-mL Eppendorf tubes using a cut 1-mL tip to avoid mechanical damage of the cells. Each tube was treated as a biological replicate. At least three replicates were used for each condition in each experiment.

The tubes were exposed to four conditions: (i) left on the bench at room temperature; incubated for $10 \mathrm{~min}$ at (ii) $55^{\circ} \mathrm{C}$ or (iii) $85^{\circ} \mathrm{C}$ in a preheated thermoblock (wells were filled with water for better thermoconductivity); (iv) snap frozen in liquid nitrogen. After treatments, cultures were left to cool down or thaw for $5 \mathrm{~min}$ at room temperature and then either mounted on a sample glass to be imaged using confocal laser scanning microscopy (CLSM) or processed further for quantitative assay.

For quantitative fluorescein leakage assay, cells were pelleted on nylon meshes with $50-\mu \mathrm{m}$ pores. Supernatants were collected entirely with a pipette, $150 \mu \mathrm{L}$ of each supernatant were transferred to the empty wells of a 96-well flat bottom plate (Sarstedt). Cells on the mesh were then washed off the meshes into wells of the same plate using $150 \mu \mathrm{L}$ of fresh BY-2 media. Fluorescence was measured in the FLUOstar Omega Microplate Reader (BMG LABTECH) using $485 \mathrm{~nm}$ excitation/520 $\mathrm{nm}$ emission filters (gain 800, 20 flashes/well). Importantly, the measurement had to be performed within 20 min after treatment to avoid passive diffusion of fluorescein into extracellular space in the control samples. Leaked fluorescein intensity was calculated for each sample as a percentage of total fluorescence intensity detected in the cells and supernatant. A one-way ANOVA with Dunnet's test was performed using JMP 10, and the graph was built in Origin2019.

\section{Sytox Orange and FM4-64 staining}

Aliquots of 4-5-day-old BY-2 cell culture were transferred to 1.5-mL Eppendorf tubes using a cut 1-mL tip. The final concentrations of Sytox Orange (SO) and FM4-64 in cell culture were $1 \mu \mathrm{M}$ and $0.5 \mu \mathrm{M}$, respectively. Depending on experimental design, four different staining protocols were applied to the cell cultures: (i) As a control, stained cell culture was incubated on the lab bench for $30 \mathrm{~min}$. (ii) Stained cell culture was incubated in a preheated thermoblock for a 10-min HS. (iii) Cell culture was subjected to a HS for $10 \mathrm{~min}$ and stained after additional $30 \mathrm{~min}$ at room temperature. (iv) For multi-day $(72 \mathrm{~h})$ experiments, cell culture was subjected to a HS for $10 \mathrm{~min}$, and stains were applied 10 min before observation. Cells were mounted on a microscope slide and imaged by CLSM after staining. More than one hundred cells were counted for each treatment to ensure robustness of the results. Note that there is some degree of crosstalk in the fluorescence emission profiles of the SO and FM4-64 stains, which was most 


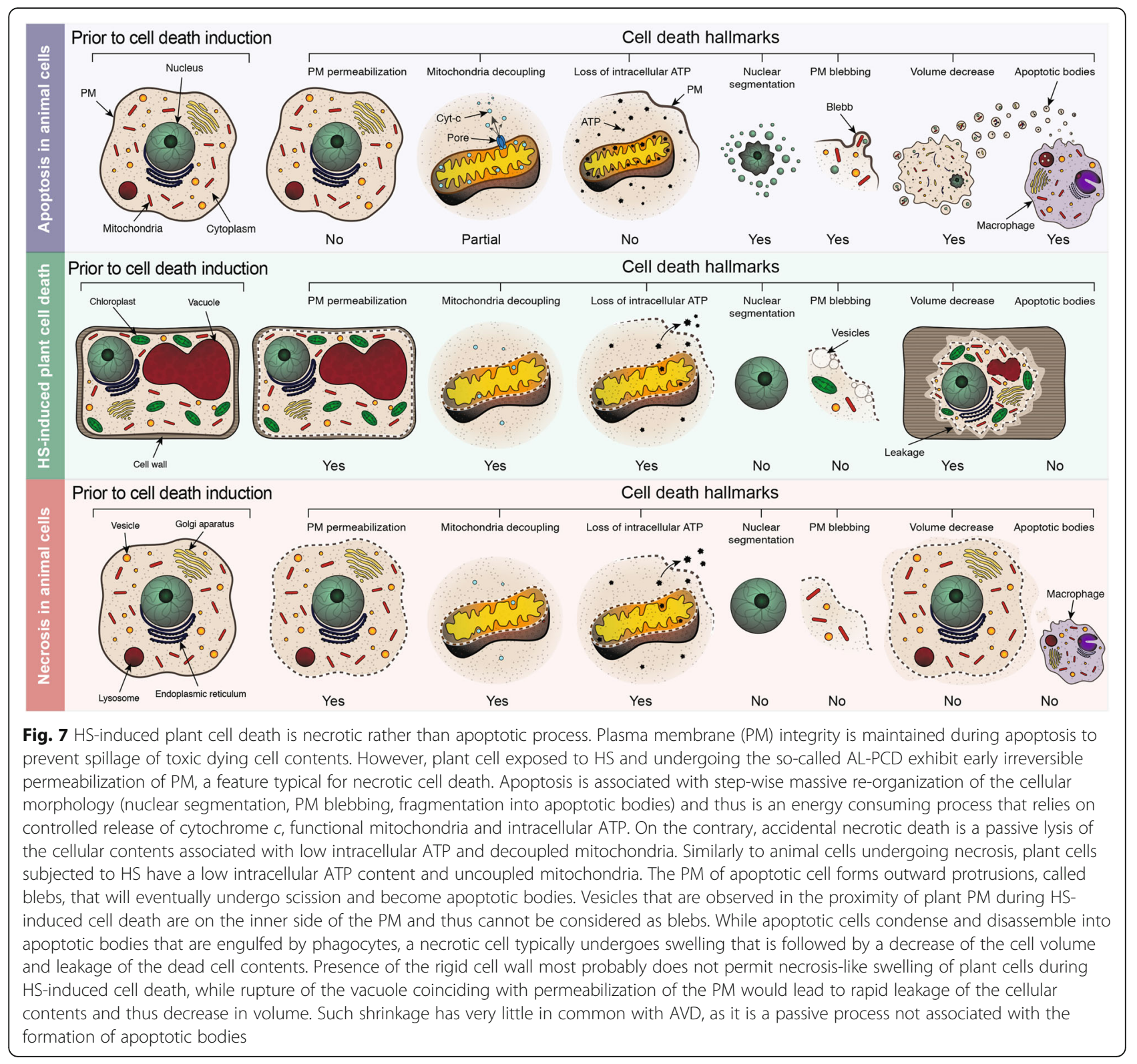

prominent following $85^{\circ} \mathrm{C} \mathrm{HS}$; however, this crosstalk had no influence on the results of our experiments.

\section{Nuclear phenotyping}

A transgenic BY-2 line expressing GFP fused to NLS under a double $35 \mathrm{~S}$ promoter $(2 \times 35::$ Rluc-sGFP-NLS $)$ was used to evaluate nuclear phenotype following HS. The transgenic culture was generated according to [107]. Treatments included the following: (i) No HS, (ii) 10-min pulse $\mathrm{HS}$ at $55^{\circ} \mathrm{C}$, (iii) 10 -min pulse $\mathrm{HS}$ at $55^{\circ} \mathrm{C}$ with SO staining as stated above, which was used to validate results following HS (data not shown). Six hours following HS, zstack acquisitions were captured with Zeiss LSM 800 as described in the "Confocal microscopy" section. Quantification was performed using maximum intensity projections. The areas of nuclei were approximated using threshold segmentation of images with Fiji software (ImageJ version 1.52r). Three independent experiments were carried out.

\section{MitoTracker red staining}

BY-2 cells were stained with $100 \mu \mathrm{M}$ MitoTracker Red (Thermo Fisher, M7512) for $10 \mathrm{~min}$ at room temperature. Cells were mounted on a microscope slide and imaged using Zeiss LSM 780 as described in the "Confocal microscopy" section.

\section{EGTA and cyclosporin a treatments}

Half a millilitre of a 4-5-day-old BY-2 cell culture was transferred to 1.5-mL Eppendorf tubes. The cells were 
stained with MitoTracker Red $(100 \mu \mathrm{M})$ and FDA $(2 \mu \mathrm{g} /$ $\mathrm{mL}) 10 \mathrm{~min}$ prior to treatment. Four different treatments (all at room temperature) were applied prior to $10-\mathrm{min}$ $\mathrm{HS}$ at $55^{\circ} \mathrm{C}$ : (i) $10 \mathrm{mM}$ EGTA, pH 8.0 for $10 \mathrm{~min}$, (ii) $0.1 \%$ DMSO for $2 \mathrm{~h}$, (iii) $15 \mu \mathrm{M}$ CsA for $2 \mathrm{~h}$ and (iv) 10 mM EGTA (applied $10 \mathrm{~min}$ prior to HS) and $15 \mu \mathrm{M}$ CsA (applied $2 \mathrm{~h}$ prior to HS). Treatment times were staggered and samples were scanned within $10 \mathrm{~min}$ following HS. Cells were mounted on a microscope slide and imaged using Zeiss LSM 800.

In order to assess the cell death rate following EGTA treatment, an additional experiment was carried out using BY-2 cells that were treated and then stained with SO and FM4-64. There were three biological replicates for each treatment group: (i) No HS, control (water), (ii) No HS, with EGTA, (iii) 10 -min $55^{\circ} \mathrm{C}$ HS, control, and (iv) 10 -min $55^{\circ} \mathrm{C}$ HS, with EGTA. After HS, $300 \mu \mathrm{L}$ of each sample was transferred to a 24-well plate designed for fluorescent microscopy ( $\mu$-Plate 24, Ibidi 82406) and imaged using Zeiss LSM 780 as described in the "Confocal microscopy" section.

\section{ATP content measurement}

The assay was performed based on the previously published protocol [108]. Half a millilitre aliquots of a 4day-old BY-2 cell culture were transferred with a cut tip into 2-mL Eppendorf tubes. Six replicates were measured for each treatment in each experiment. The aliquoted cells were subjected to the treatments described in the "Fluorescein leakage assay (fluorochromatic assay)". Additionally, six aliquots were incubated with $48 \mu \mathrm{M}$ CCCP on the bench for $1 \mathrm{~h}$. After treatment, cells were pelleted on a nylon mesh with $50-\mu \mathrm{m}$ pores, rinsed with $3 \mathrm{~mL}$ of medium and washed off into new Eppendorf tubes with $600 \mu \mathrm{L}$ of boiling buffer $(100 \mathrm{mM}$ Tris$\mathrm{HCl}, 4 \mathrm{mM}$ EDTA, pH 7.5, autoclaved and supplemented with phosphatase inhibitor cocktail 2 (Sigma-Aldrich, P5726)). During sample collection, the tubes were kept on ice. Samples were then boiled at $100^{\circ} \mathrm{C}$ for 10 min, and debris was spun down at $4{ }^{\circ} \mathrm{C}, 10,000 \mathrm{~g}$ for 20 min. The supernatants were transferred into new tubes and stored on ice.

For each sample, $83.5 \mu \mathrm{L}$ of supernatant were transferred into wells of white Nunc plates in three technical replicates. The background signal was detected using FLUOstar Omega Microplate Reader (BMG LABTECH), with a lens filter taking ten measurements per well. $41.5 \mu \mathrm{L}$ of freshly prepared reaction buffer $(1.5 \mathrm{mM}$ DTT, $100 \mu \mathrm{M}$ Luciferin (Sigma L 6152) and $5 \mu \mathrm{g} / \mathrm{mL} \mathrm{Lu-}$ ciferase from Phontius pyralis (Sigma L9506)) were pipetted into each well by the automated pump in a microplate reader. Luminescence was detected for each well after adding the reaction buffer and shaking the plate to ensure good mixing in the reaction volume. A serial dilution of ATP ranging from $1.810^{-2} \mathrm{M}$ to $10^{-8}$ $\mathrm{M}$ was used to build a standard curve and calculate the amount of ATP in each sample. A one-way ANOVA with Dunnet's test was performed using JMP 10, and the graph was built in Origin 2019.

\section{CCCP treatment}

Half a millilitre of 4-5-day-old BY-2 cell culture was transferred to $1.5-\mathrm{mL}$ Eppendorf tubes using a cut 1-mL tip. Staining with SO and FM4-64 was performed as described above (protocols $i$ and ii for no HS and HS treatment groups, respectively). The four treatment groups included as follows: (i) 10-min treatment with $48 \mu \mathrm{M}$ CCCP at room temperature followed by $55^{\circ} \mathrm{C}$ HS for 10 min, (ii) $0.1 \%$ DMSO (vehicle control) at room temperature for $10 \mathrm{~min}$ followed by $55^{\circ} \mathrm{HS}$ for $10 \mathrm{~min}$, (iii) 10-min treatment with $48 \mu \mathrm{M} \mathrm{CCCP}$ and no HS and (iv) $0.1 \%$ DMSO with no HS. The cultures were transferred to a 24-well plate designed for fluorescent microscopy ( $\mu$-Plate 24, Ibidi 82406). Scanning of the wells was performed automatically using CLSM, 10 min after treatment and then every $2 \mathrm{~h}$ for $24 \mathrm{~h}$. Three replicates were carried out per treatment group.

A HS gradient experiment was also carried out, comparing control (DMSO) and CCCP-treated BY-2 cells. The cultures were stained and treated as per the CCCP experiment described above and then subjected to one of the following conditions: (i) no $\mathrm{HS}$, (ii) $40^{\circ} \mathrm{C}$, (iii) $45^{\circ} \mathrm{C}$, (iv) $50^{\circ} \mathrm{C}$ or (v) $55^{\circ} \mathrm{C} \mathrm{HS}$ for $10 \mathrm{~min}$. The cultures were scanned after $6 \mathrm{~h}$ and $24 \mathrm{~h}$ using CLSM. Three technical replicates were carried out per group.

\section{Osmotic stress assay}

Half a millilitre of 4-5-day-old BY-2 cell culture was transferred to $1.5-\mathrm{mL}$ Eppendorf tubes using a cut 1-mL tip. Cells were stained with FDA and exposed to HS as described in the "Fluorescein leakage assay (fluorochromatic assay)". D-Mannitol was pre-measured and added to Eppendorf tubes so that the addition of $200 \mu \mathrm{L}$ of culture would give a final concentration of $500 \mathrm{mM}$. After $\mathrm{HS}$, the cultures were allowed to cool for $10 \mathrm{~min}$ at $25^{\circ} \mathrm{C}$ and then $200 \mu \mathrm{L}$ were transferred to the tubes containing D-Mannitol. The cultures were mixed gently by pipetting to dissolve the D-Mannitol. Within $30 \mathrm{~min}$ of DMannitol treatment, the samples were mounted on a sample glass and imaged using Zeiss LSM 800.

\section{Ferroptosis assays}

Three millilitres of 4-5-day-old BY-2 cell culture were transferred to a 6-well plate using a cut $1-\mathrm{mL}$ tip. Five different treatments were applied to the cell cultures for $16 \mathrm{~h}$ during which time they were returned to the incubator and grown as described above: (i) 0.1\% DMSO (vehicle control), (ii) $1 \mu \mathrm{M}$ Fer-1 (Sigma SML0583), (iii) 
$10 \mu \mathrm{M}$ Fer-1, (iv) $50 \mu \mathrm{M}$ Fer-1 and (v) $100 \mu \mathrm{M}$ Fer-1. After the 16-h treatments, $0.5 \mathrm{~mL}$ of culture from each well was transferred to $1.5 \mathrm{~mL}$ Eppendorf tubes using a cut 1-mL tip and separated into three treatments: (i) no $\mathrm{HS}$, (ii) $55^{\circ} \mathrm{HS}$ for $10 \mathrm{~min}$ or (iii) $85^{\circ} \mathrm{HS}$ for $10 \mathrm{~min}$ as described above. Following treatment, $10 \mu \mathrm{L}$ of culture were transferred to $490 \mu \mathrm{L}$ of fresh BY-2 media in 24well plates designed for fluorescent microscopy ( $\mu$-Plate 24, Ibidi 82406). Staining with SO and FM4-64 was performed as described above (protocols i and iii for no HS and HS treatment groups, respectively). Three technical replicates were carried out for each group, and the wells were scanned automatically using CLSM at the following intervals: $10 \mathrm{~min}, 3,6,9,12,15,18,21$ and $24 \mathrm{~h}$. Three independent experiments were carried out.

The effect of Fer-1 was also tested on Arabidopsis thaliana seedlings using a protocol previously reported within the literature [89]. Arabidopsis seedlings were grown as described above and after six days they were gently transferred to 6 -well plates containing $3 \mathrm{~mL}$ of liquid half-strength MS medium and given one of the following three treatments for $16 \mathrm{~h}$ : (i) $0.1 \%$ DMSO (vehicle control), (ii) $1 \mu \mathrm{M}$ Fer-1 and (iii) $10 \mu \mathrm{M}$ Fer-1. The medium was pipetted gently over the seedlings to ensure that roots were submerged in the liquid prior to being placed back into the growth cabinet overnight. The following morning, the seedlings were carefully transferred to $1.5-\mathrm{mL}$ Eppendorf tubes containing the same treatment media from the 6-well plates before subjection to one of the following three treatments: (i) no $\mathrm{HS}$, (ii) $55^{\circ} \mathrm{HS}$ for $10 \mathrm{~min}$ or (iii) $85^{\circ} \mathrm{HS}$ for $10 \mathrm{~min}$ as described above. The seedlings were then stained with SO and FM4-64 as described above (protocols i and iii for no HS and HS treatment groups, respectively) and placed back into the growth cabinet until scanning with CLSM at $3 \mathrm{~h}$ and $6 \mathrm{~h}$ post-HS. The early differentiation zone of the root was scanned for three seedlings per time point, and three independent experiments were carried out.

\section{Confocal microscopy}

Micrographs were acquired using either a LSM 800 or LSM 780 confocal laser scanning microscope (Carl Zeiss) with GaAsP detectors. Micrographs were taken with four different objectives: $\times 10$ (NA0.45), $\times 20$ $($ NA0.8), $\times 40$ (NA1.2, water immersion) and $\times 63$ (NA1.2, water immersion). For Fig. 1a, b and supplementary video $\mathrm{S} 1, \mathrm{z}$-stack acquisition with sequential scanning was performed with $a \times 63$ objective. Nuclear phenotyping using the BY-2 transgenic line (Fig. 1c) was done with $\mathrm{z}$-stack acquisitions using a $\times 20$ objective. Fluorescein was excited at $488 \mathrm{~nm}$ and emission was detected from 499 to $560 \mathrm{~nm}$. MitoTracker red was excited at $561 \mathrm{~nm}$ and emission was detected from 582 to 754 $\mathrm{nm}$. SO was excited at $561 \mathrm{~nm}$ and emission was detected from 410 to $605 \mathrm{~nm}$. FM4-64 excitation was 506 $\mathrm{nm}$, and the emission was detected from 650 to $700 \mathrm{~nm}$. Images were acquired using ZEN blue software (version 2.5, Carl Zeiss) or Zen black (version 2.3).

\section{Abbreviations}

AL-PCD: Apoptosis-like programmed cell death; AVD: Apoptotic volume decrease; Bcl-2: B cell lymphoma 2; BY-2: Bright Yellow-2 cells;

CCCP: Carbonyl cyanide m-chlorophenylhydrazone; CLSM: Confocal laser scanning microscopy; CsA: Cyclosporin A; DIC: Differential interference contrast; EGTA: Ethylene glycol-bis (2-aminoethylether)-N,N,N',N'-tetraacetic acid; FDA: Fluorescein diacetate; Fer-1: Ferrostatin-1; GFP: Green fluorescent protein; HS: Heat shock; IQR: Interquartile range; MMP: Mitochondrial membrane potential; MPT: Mitochondrial permeability transition; MPTP: Mitochondrial permeability transition pore; MS: Murashige and Skoog medium; NLR: Nod-like receptor; NLS: Nuclear localization signal; PCD: Programmed cell death; PM: Plasma membrane; RCD: Regulated cell death; SO: Sytox Orange

\section{Supplementary Information}

Supplementary information accompanies this paper at https://doi.org/10. 1186/s12915-021-01018-z.

\begin{abstract}
Additional file 1. Video S1. Shrinkage of plant protoplast caused by $55^{\circ} \mathrm{C} \mathrm{HS}$ is not followed by fragmentation into apoptotic bodies. 3D reconstructions (maximum intensity projections) of FM4-64-stained BY-2 cells to visualize the PM. Staining was performed according to protocols i and ii for the control conditions (no HS) and HS treatments, respectively (see Methods, Sytox Orange and FM4-64 staining). The arrows indicate membrane structure vaguely resembling PM blebbing or apoptotic bodies, which were not observed in the control (no HS) sample. These structures are localized on the inner side of the PM and do not separate from the cell even at late stages of cell death. Scale bars, $20 \mu \mathrm{m}$.

Additional file 2: Figure S1. Time course analysis of gross morphological changes following $55^{\circ} \mathrm{C} \mathrm{HS}$. FM4-64 and SO dyes were used to visualize collapsed cells with permeabilized PM. After a 10-min $\mathrm{HS}$ at $55^{\circ} \mathrm{C}$, BY-2 cells were stained and imaged at several time points ranging from $15 \mathrm{~min}$ to $72 \mathrm{~h}$. Staining was performed as described in protocol iv (see Methods, Sytox Orange and FM4-64 staining). FM4-64 panels represent the corresponding boxed areas. Arrows indicate FM4-64 positive vesicles that were found within the boundaries of cell corpses. DIC, differential interference contrast. Scale bars, 20 um. Figure S2. HSinduced cell death is ATP- and $\mathrm{Ca}^{2+}$-independent process. Morphology of FDA-stained cells under normal conditions (No HS) and after a $55^{\circ} \mathrm{C} \mathrm{HS}$. Protoplast shrinkage is denoted by arrows. Pre-treatment with $48 \mu \mathrm{M}$ CCCP for $10 \mathrm{~min}, 15 \mu \mathrm{M}$ CsA for $2 \mathrm{~h}$, or $10 \mathrm{mM}$ EGTA for $10 \mathrm{~min}$ did not alleviate protoplast shrinkage upon HS. Each treatment was repeated at least twice. Scale bars, $20 \mu \mathrm{m}$.
\end{abstract}

\section{Acknowledgements}

We would like to thank Prof. S. Kamoun for the insightful comments to the preprint version of this work published on BioRxiv.

\section{Authors' contributions}

EAM, APS and PVB developed the concept of this study and are main contributors to writing the manuscript. EAM, AND and FB performed all experiments, analysed data and prepared figures. VG contributed to the discussions of the results. All authors read and approved the final manuscript.

\section{Funding}

This project was supported by grants from Carl Tryggers Foundation (to EAM), MSCA IF (799433, to EAM), the Swedish Research Councils VR (to PVB) and Formas (to AND and PVB), the Knut and Alice Wallenberg Foundation (to PVB), the Swedish Foundation for Strategic Research (to PVB), the Natural Sciences and Engineering Research Council (NSERC) of Canada (to AND) and by the research programme "Crops for the Future" at the Swedish University 
of Agricultural Sciences. APS is grateful to August T. Larsson Guest Researcher Programme for supporting his visits to the Swedish University of Agricultural Sciences. VG was supported by the Russian Science Foundation (grant 19-14-00122). Open Access funding was provided by Swedish University of Agricultural Sciences.

\section{Availability of data and materials}

Data generated and analysed during this study are included in the published article and its supplementary information files.

\section{Declarations}

\section{Ethics approval and consent to participate}

Not applicable.

\section{Consent for publication}

Not applicable.

\section{Competing interests}

The authors declare no competing interests.

\section{Author details}

'Department of Molecular Sciences, Uppsala BioCenter, Swedish University of Agricultural Sciences and Linnean Center for Plant Biology, P.O. Box 7015, SE-750 07 Uppsala, Sweden. ${ }^{2}$ COS, Heidelberg University, Im Neuenheimer Feld 230, 69120 Heidelberg, Germany. ${ }^{3}$ Institute of Environmental Medicine, Division of Toxicology, Karolinska Institutet, Box 210, SE-171 77 Stockholm, Sweden. ${ }^{4}$ Faculty of Medicine, MV Lomonosov Moscow State University, 119991 Moscow, Russia. ${ }^{5}$ Institute of Biological Chemistry, College of Human, Agricultural, and Natural Resource Sciences, Washington State University, Pullman, WA 99164, USA.

\section{Received: 3 September 2020 Accepted: 1 April 2021}

Published online: 12 May 2021

\section{References}

1. Galluzzi L, Bravo-San Pedro JM, Vitale I, Aaronson SA, Abrams JM, Adam D, et al. Essential versus accessory aspects of cell death: recommendations of the NCCD 2015. Cell Death Differ. 2015;22(1):58-73. https://doi.org/10.1038/ cdd.2014.137.

2. Jacobson MD, Weil M, Raff MC. Programmed cell death in animal development. Cell. 1997:88(3):347-54. https://doi.org/10.1016/S0092-8674 (00)81873-5

3. Suzanne M, Steller H. Shaping organisms with apoptosis. Cell Death Differ. 2013;20(5):669-75. https://doi.org/10.1038/cdd.2013.11.

4. Daneva A, Gao Z, Van Durme M, Nowack MK. Functions and regulation of programmed cell death in plant development. Annu Rev Cell Dev Biol. 2016;32(1):441-68. https://doi.org/10.1146/annurev-cellbio-111315-124915.

5. Huysmans M, Lema AS, Coll NS, Nowack MK. Dying two deaths programmed cell death regulation in development and disease. Curr Opin Plant Biol. 2017;35:37-44. https://doi.org/10.1016/j.pbi.2016.11.005

6. Coll NS, Epple P, Dangl JL. Programmed cell death in the plant immune system. Cell Death Differ. 2011;18(8):1247-56. https://doi.org/10.1038/cdd.2 011.37.

7. Jorgensen I, Rayamajhi M, Miao EA. Programmed cell death as a defence against infection. Nat Rev Immunol. 2017;17(3):151-64. https://doi.org/10.1 038/nri.2016.147

8. Kerr JF, Wyllie AH, Currie AR. Apoptosis: a basic biological phenomenon with wide-ranging implications in tissue kinetics. Br J Cancer. 1972;26(4): 239-57. https://doi.org/10.1038/bjc.1972.33.

9. Letai A. Apoptosis and Cancer. Annu Rev Cancer Biol. 2017;1(1):275-94. https://doi.org/10.1146/annurev-cancerbio-050216-121933.

10. Kroemer G, El-Deiry WS, Golstein P, Peter ME, Vaux D, Vandenabeele P, et al. Classification of cell death: recommendations of the Nomenclature Committee on Cell Death. Cell Death Differ. 2005;12(Suppl 2):1463-7. https://doi.org/10.1038/sj.cdd.4401724.

11. van Doorn WG, Beers EP, Dangl JL, Franklin-Tong VE, Gallois P, HaraNishimura I, et al. Morphological classification of plant cell deaths. Cell Death Differ. 2011;18(8):1241-6. https://doi.org/10.1038/cdd.2011.36.
12. Murat F, van de Peer Y, Salse J. Decoding plant and animal genome plasticity from differential paleo-evolutionary patterns and processes. Genome Biol Evol. 2012;4(9):917-28. https://doi.org/10.1093/gbe/evs066.

13. Drost H-G, Janitza P, Grosse I, Quint M. Cross-kingdom comparison of the developmental hourglass. Curr Opin Genet Dev. 2017;45:69-75. https://doi. org/10.1016/j.gde.2017.03.003.

14. Fritz-Laylin LK. The evolution of animal cell motility. Curr Biol. 2020;30(10): R477-82. https://doi.org/10.1016/j.cub.2020.03.026.

15. Fulcher N, Sablowski R. Hypersensitivity to DNA damage in plant stem cell niches. Proc Natl Acad Sci. 2009;106(49):20984 LP-20988.

16. De Zio D, Cianfanelli V, Cecconi F. New insights into the link between DNA damage and apoptosis. Antioxid Redox Signal. 2013;19(6):559-71. https:// doi.org/10.1089/ars.2012.4938.

17. Arandjelovic S, Ravichandran KS. Phagocytosis of apoptotic cells in homeostasis. Nat Immunol. 2015;16(9):907-17. https://doi.org/10.1038/ni.3253.

18. Galluzzi L, Vitale I, Aaronson SA, Abrams JM, Adam D, Agostinis P, et al. Molecular mechanisms of cell death: recommendations of the Nomenclature Committee on Cell Death 2018. Cell Death Differ. 2018;25(3): 486-541. https://doi.org/10.1038/s41418-017-0012-4.

19. Degterev A, Yuan J. Expansion and evolution of cell death programmes. Nat Rev Mol Cell Biol. 2008;9(5):378-90. https://doi.org/10.1038/nrm2393.

20. Sperandio S, Belle I, Bredesen DE. An alternative, nonapoptotic form of programmed cell death. Proc Natl Acad Sci U S A. 2000;97(26):14376-81. https://doi.org/10.1073/pnas.97.26.14376.

21. Molnár T, Mázló A, Tslaf V, Szöllősi AG, Emri G, Koncz G. Current translational potential and underlying molecular mechanisms of necroptosis. Cell Death Dis. 2019;10(11):860. https://doi.org/10.1038/s41419-019-2094-z.

22. Dixon SJ, Stockwell BR. The hallmarks of Ferroptosis. Annu Rev Cancer Biol. 2019;3(1):35-54. https://doi.org/10.1146/annurev-cancerbio-030518055844

23. Miao EA, Leaf IA, Treuting PM, Mao DP, Dors M, Sarkar A, et al. Caspase-1induced pyroptosis is an innate immune effector mechanism against intracellular bacteria. Nat Immunol. 2010;11(12):1136-42. https://doi.org/10.1 038/ni.1960

24. Ameisen JC. On the origin, evolution, and nature of programmed cell death a timeline of four billion years. Cell Death Differ. 2002;9(4):367-93. https:// doi.org/10.1038/sj.cdd.4400950.

25. Bozhkov PV, Lam E. Green death: revealing programmed cell death in plants. Cell Death Differ. 2011;18(8):1239-40. https://doi.org/10.1038/cdd.2 011.86

26. Sueldo DJ, van der Hoorn RAL. Plant life needs cell death, but does plant cell death need Cys proteases? FEBS J. 2017;284(10):1577-85. https://doi. org/10.1111/febs.14034.

27. Uren AG, O'Rourke K, Aravind L, Pisabarro MT, Seshagiri S, Koonin EV, et al. Identification of paracaspases and metacaspases. Mol Cell. 2000;6(4):961-7.

28. Salvesen GS, Hempel A, Coll NS. Protease signaling in animal and plantregulated cell death. FEBS J. 2016;283(14):2577-98. https://doi.org/10.1111/ febs.13616.

29. Tsiatsiani L, Van Breusegem F, Gallois P, Zavialov A, Lam E, Bozhkov PV. Metacaspases. Cell Death Differ. 2011;18(8):1279-88. https://doi.org/10.1038/ cdd.2011.66

30. Minina EA, Coll NS, Tuominen H, Bozhkov PV. Metacaspases versus caspases in development and cell fate regulation. Cell Death Differ. 2017;24(8):131425. https://doi.org/10.1038/cdd.2017.18

31. Vercammen D, van de Cotte B, De Jaeger G, Eeckhout D, Casteels P, Vandepoele K, et al. Type II metacaspases Atmc4 and Atmc9 of Arabidopsis thaliana cleave substrates after arginine and lysine. J Biol Chem. 2004; 279(44):45329-36. https://doi.org/10.1074/jbc.M406329200.

32. Minina EA, Staal J, Alvarez VE, Berges JA, Berman-Frank I, Beyaert R, et al. Classification and nomenclature of metacaspases and paracaspases: no more confusion with caspases. Mol Cell. 2020;77(5):927-9. https://doi.org/1 0.1016/j.molcel.2019.12.020

33. Edlich F. BCL-2 proteins and apoptosis: recent insights and unknowns. Biochem Biophys Res Commun. 2018;500(1):26-34. https://doi.org/10.1016/j. bbrc.2017.06.190.

34. Lacomme C, Santa CS. Bax-induced cell death in tobacco is similar to the hypersensitive response. Proc Natl Acad Sci U S A. 1999;96(14):7956-61. https://doi.org/10.1073/pnas.96.14.7956.

35. Mitsuhara I, Malik KA, Miura M, Ohashi Y. Animal cell-death suppressors BclXL and Ced-9 inhibit cell death in tobacco plants. Curr Biol. 1999.9(14):775S1. https://doi.org/10.1016/S0960-9822(99)80341-8. 
36. Yu X-H, Perdue TD, Heimer YM, Jones AM. Mitochondrial involvement in tracheary element programmed cell death. Cell Death Differ. 2002;9(2):18998. https://doi.org/10.1038/sj.cdd.4400940.

37. Martínez-Fábregas J, Díaz-Moreno I, González-Arzola K, Janocha S, Navarro JA, Hervás M, et al. Mol Cell Proteomics. 2013;12(12):3666-76. https://doi. org/10.1074/mcp.M113.030692.

38. Dickman M, Williams B, Li Y, Figueiredo P, Wolpert T. Reassessing apoptosis in plants. Nat plants. 2017;3(10):773-9. https://doi.org/10.1038/s41477-0170020-x.

39. Kabbage M, Kessens R, Bartholomay LC, Williams B. The life and death of a plant cell. Annu Rev Plant Biol. 2017;68(1):375-404. https://doi.org/10.1146/a nnurev-arplant-043015-111655.

40. Tixeira R, Poon IKH. Disassembly of dying cells in diverse organisms. Cell Mol Life Sci. 2019;76(2):245-57. https://doi.org/10.1007/s00018-018-2932-7.

41. Valandro F, Menguer PK, Cabreira-Cagliari C, Margis-Pinheiro M, Cagliari A. Programmed cell death (PCD) control in plants: new insights from the Arabidopsis thaliana deathosome. Plant Sci. 2020;299:110603. https://doi. org/10.1016/j.plantsci.2020.110603.

42. Tsujimoto Y. Apoptosis and necrosis: intracellular ATP level as a determinant for cell death modes. Cell Death Differ. 1997;4(6):429-34. https://doi.org/10.1 038/sj.cdd. 4400262.

43. Hengartner MO. The biochemistry of apoptosis. Nature. 2000;407(6805):7706. https://doi.org/10.1038/35037710.

44. Segawa K, Nagata S. An apoptotic "eat me" signal: phosphatidylserine exposure. Trends Cell Biol. 2015;25(11):639-50. https://doi.org/10.1016/j.tcb.2 015.08.003.

45. Zhang Y, Chen X, Gueydan C, Han J. Plasma membrane changes during programmed cell deaths. Cell Res. 2018;28(1):9-21. https://doi.org/10.1038/ cr.2017.133.

46. Galluzzi L, Vitale I, Abrams JM, Alnemri ES, Baehrecke EH, Blagosklonny MV, et al. Molecular definitions of cell death subroutines: recommendations of the nomenclature committee on cell death 2012. Cell Death Differ. 2012; 19(1):107-20. https://doi.org/10.1038/cdd.2011.96.

47. Atkin-Smith GK, Poon IKH. Disassembly of the dying: mechanisms and functions. Trends Cell Biol. 2017;27(2):151-62. https://doi.org/10.1016/j.tcb.2 016.08.011.

48. Balk J, Leaver CJ, McCabe PF. Translocation of cytochrome $\mathrm{c}$ from the mitochondria to the cytosol occurs during heat-induced programmed cell death in cucumber plants. FEBS Lett. 1999;463(1-2):151-4. https://doi.org/1 0.1016/S0014-5793(99)01611-7.

49. Vacca RA, Pinto MC, Valenti D, Passarella S, Marra E, Gara L. Production of reactive oxygen species, alteration of cytosolic ascorbate peroxidase, and impairment of mitochondrial metabolism are early events in heat shockinduced programmed cell death in tobacco bright-yellow 2 cells. Plant Physiol. 2004;134(3):1100-12. https://doi.org/10.1104/pp.103.035956.

50. Hogg BV, Kacprzyk J, Molony EM, O'Reilly C, Gallagher TF, Gallois P, et al. An in vivo root hair assay for determining rates of apoptotic-like programmed cell death in plants. Plant Methods. 2011;7(1):45. https://doi.org/10.1186/174 6-4811-7-45.

51. Kacprzyk J, Brogan NP, Daly CT, Doyle SM, Diamond M, Molony EM, McCabe PF. The retraction of the protoplast during PCD is an active, and interruptible, calcium-flux driven process. Plant Sci. 2017;260:50-9. https:// doi.org/10.1016/j.plantsci.2017.04.001.

52. Curtis MJ, Wolpert TJ. The victorin-induced mitochondrial permeability transition precedes cell shrinkage and biochemical markers of cell death, and shrinkage occurs without loss of membrane integrity. Plant J. 2004; 38(2):244-59. https://doi.org/10.1111/j.1365-313X.2004.02040.X.

53. Mlejnek $P$, Doležel $P$, Procházka S. Intracellular phosphorylation of benzyladenosine is related to apoptosis induction in tobacco BY-2 cells. Plant Cell Environ. 2003;26(10):1723-35. https://doi.org/10.1046/j.1365-3040.2 003.01090.x

54. Zhang Q-F, Li J, Bi F-C, Liu Z, Chang Z-Y, Wang L-Y, et al. Ceramide-induced cell death depends on calcium and caspase-like activity in Rice. Front Plant Sci. 2020;11:145. https://doi.org/10.3389/fpls.2020.00145.

55. Vacca RA, Valenti D, Bobba A, Merafina RS, Passarella S, Marra E. Cytochrome $C$ is released in a reactive oxygen species-dependent manner and is degraded via caspase-like proteases in tobacco bright-yellow 2 cells en route to heat shock-induced cell death. Plant Physiol. 2006;141(1):208-19. https://doi.org/10.1104/pp.106.078683.

56. Shi Y. Mechanisms of caspase activation and inhibition during apoptosis Mol Cell. 2002;9(3):459-70. https://doi.org/10.1016/S1097-2765(02)00482-3.
57. Wang J, Li X, Liu Y, Zhao X. Salt stress induces programmed cell death in Thellungiella halophila suspension-cultured cells. J Plant Physiol. 2010; 167(14):1145-51. https://doi.org/10.1016/j.jplph.2010.03.008.

58. Coffeen WC, Wolpert TJ. Purification and characterization of serine proteases that exhibit caspase-like activity and are associated with programmed cell death in Avena sativa. Plant Cell. 2004;16(4):857-73. https://doi.org/10.1105/ tpc.017947.

59. Żabka A, Winnicki K, Polit JT, Maszewski J. Sanguinarine-induced oxidative stress and apoptosis-like programmed cell death (AL-PCD) in root meristem cells of Allium cepa. Plant Physiol Biochem PPB. 2017;112:193-206. https:// doi.org/10.1016/j.plaphy.2017.01.004.

60. Danon A, Rotari VI, Gordon A, Mailhac N, Gallois P. Ultraviolet-C overexposure induces programmed cell death in Arabidopsis, which is mediated by caspase-like activities and which can be suppressed by caspase inhibitors, p35 and defender against apoptotic death. J Biol Chem. 2004;279(1):779-87. https://doi.org/10.1074/jbc.M304468200.

61. McCabe PF, Levine A, Meijer P-J, Tapon NA, Pennell RI. A programmed cell death pathway activated in carrot cells cultured at low cell density. Plant J. 1997;12(2):267-80. https://doi.org/10.1046/j.1365-313X.1997.12020267.x.

62. Coimbra S, Torrão L, Abreu I. Programmed cell death induces male sterility in Actinidia deliciosa female flowers. Plant Physiol Biochem PPB. 2004;42(6): 537-41. https://doi.org/10.1016/j.plaphy.2004.05.004.

63. Li W, Dickman MB. Abiotic stress induces apoptotic-like features in tobacco that is inhibited by expression of human Bcl-2. Biotechnol Lett. 2004;26(2): 87-95. https://doi.org/10.1023/B:BILE.0000012896.76432.ba.

64. Li W, Kabbage M, Dickman MB. Transgenic expression of an insect inhibitor of apoptosis gene, SfIAP, confers abiotic and biotic stress tolerance and delays tomato fruit ripening. Physiol Mol Plant Pathol. 2010;74(5):363-75. https://doi.org/10.1016/j.pmpp.2010.06.001.

65. Hou L, Liu K, Li Y, Ma S, Ji X, Liu L. Necrotic pyknosis is a morphologically and biochemically distinct event from apoptotic pyknosis. J Cell Sci. 2016; 129(16):3084-90. https://doi.org/10.1242/jcs.184374.

66. Moharikar S, D'Souza JS, Kulkarni AB, Rao BJ. Apoptotic-like cell death pathway is induced in unicellular chlorophyte Chlamydomonas reinhardtii (Chlorophyceae) cells following UV irradiation: detection and functional analyses. J Phycol. 2006:42(2):423-33. https://doi.org/10.1111/j.1529-8817.2 006.00207.x

67. O'Brien IE, Reutelingsperger $C P$, Holdaway KM. Annexin- $V$ and TUNEL use in monitoring the progression of apoptosis in plants. Cytometry. 1997;29(1): 28-33. https://doi.org/10.1002/(SICI)1097-0320(19970901)29:1<28::AID-CYTO2 $>3.0 . \mathrm{CO} ; 2-9$

68. Shlomovitz I, Speir M, Gerlic M. Flipping the dogma - phosphatidylserine in non-apoptotic cell death. Cell Commun Signal. 2019;17(1):139. https://doi. org/10.1186/s12964-019-0437-0.

69. Reape TJ, McCabe PF. Apoptotic-like programmed cell death in plants. New Phytol. 2008;180(1):13-26. https://doi.org/10.1111/j.1469-8137.2008.02549.x.

70. Reape TJ, McCabe PF. Commentary: the cellular condensation of dying plant cells: programmed retraction or necrotic collapse? Plant Sci. 2013;207: 135-9. https://doi.org/10.1016/j.plantsci.2013.03.001.

71. Tian R-H, Zhang G-Y, Yan C-H, Dai Y-R. Involvement of poly (ADP-ribose) polymerase and activation of caspase-3-like protease in heat shock-induced apoptosis in tobacco suspension cells. FEBS Lett. 2000;474(1):11-5. https:// doi.org/10.1016/S0014-5793(00)01561-1

72. Chen S, Vaghchhipawala Z, Li W, Asard H, Dickman MB. Tomato phospholipid hydroperoxide glutathione peroxidase inhibits cell death induced by Bax and oxidative stresses in yeast and plants. Plant Physiol. 2004;135(3):1630 LP-1641.

73. Diamond M, Reape TJ, Rocha O, Doyle SM, Kacprzyk J, Doohan FM, McCabe PF. The Fusarium mycotoxin deoxynivalenol can inhibit plant apoptosis-like programmed cell death. PLoS One. 2013;8(7):e69542. https://doi.org/10.13 71/journal.pone.0069542.

74. Malerba M, Cerana R. Effect of selenium on the responses induced by heat stress in plant cell cultures. Plants. 2018;7(3):1-10.

75. Ankarcrona M, Dypbukt JM, Bonfoco E, Zhivotovsky B, Orrenius S, Lipton SA, Nicotera P. Glutamate-induced neuronal death: a succession of necrosis or apoptosis depending on mitochondrial function. Neuron. 1995;15(4):961-73. https://doi.org/10.1016/0896-6273(95)90186-8.

76. Majno G, Joris I. Apoptosis, oncosis, and necrosis. An overview of cell death. Am J Pathol. 1995;146(1):3-15.

77. Nagata T, Nemoto Y, Hasezawa S. Tobacco BY-2 cell line as the "HeLa" cell in the cell biology of higher plants. In: Jeon KW, Friedlander M, editors. 
International review of cytologyA survey of cell biology : Volume 132. London: Elsevier; 1992. p. 1-30. (International Review of Cytology TS CrossRef; vols. 132 SV-).

78. Smetana O, Široký J, Houlné G, Opatrný Z, Chabouté M-E. Non-apoptotic programmed cell death with paraptotic-like features in bleomycin-treated plant cells is suppressed by inhibition of ATM/ATR pathways or NtE2F overexpression. J Exp Bot. 2012;63(7):2631-44. https://doi.org/10.1093/jxb/ err439.

79. Bortner CD, Cidlowski JA. Apoptotic volume decrease and the incredible shrinking cell. Cell Death Differ. 2002;9(12):1307-10. https://doi.org/10.1038/ sj.cdd. 4401126.

80. Bortner CD, Cidlowski JA. Cell shrinkage and monovalent cation fluxes: role in apoptosis. Arch Biochem Biophys. 2007;462(2):176-88. https://doi.org/10.1 016/j.abb.2007.01.020.

81. Green DR, Fitzgerald P. Just so stories about the evolution of apoptosis. Curr Biol. 2016;26(13):R620-7. https://doi.org/10.1016/j.cub.2016.05.023.

82. Hara-Nishimura I, Hatsugai N. The role of vacuole in plant cell death. Cell Death Differ. 2011;18(8):1298-304. https://doi.org/10.1038/cdd.2011.70.

83. Rotman B, Papermaster BW. Membrane properties of living mammalian cells as studied by enzymatic hydrolysis of fluorogenic esters. Proc Natl Acad Sci. 1966;55(1):134-41. https://doi.org/10.1073/pnas.55.1.134.

84. Zong W-X, Thompson CB. Necrotic death as a cell fate. Genes Dev. 2006; 20(1):1-15. https://doi.org/10.1101/gad.1376506.

85. Zamaraeva MV, Sabirov RZ, Maeno E, Ando-Akatsuka Y, Bessonova SV, Okada Y. Cells die with increased cytosolic ATP during apoptosis: a bioluminescence study with intracellular luciferase. Cell Death Differ. 2005: 12(11):1390-7. https://doi.org/10.1038/sj.cdd.4401661.

86. Perry SW, Norman JP, Barbieri J, Brown EB, Gelbard HA. Mitochondrial membrane potential probes and the proton gradient: a practical usage guide. Biotechniques. 2011;50(2):98-115. https://doi.org/10.2144/000113 610.

87. Hunter DR, Haworth RA. The Ca2+-induced membrane transition in mitochondria: I. the protective mechanisms. Arch Biochem Biophys. 1979; 195(2):453-9. https://doi.org/10.1016/0003-9861(79)90371-0.

88. Kristián T, Siesjö BK. Calcium in ischemic cell death. Stroke. 1998;29(3):70518. https://doi.org/10.1161/01.STR.29.3.705.

89. Distéfano AM, Martin MV, Córdoba JP, Bellido AM, D'Ippólito S, Colman SL, et al. Heat stress induces ferroptosis-like cell death in plants. J Cell Biol. 2017;216(2):463-76. https://doi.org/10.1083/jcb.201605110.

90. Login GR, Dvorak AM. Microwave fixation provides excellent preservation of tissue, cells and antigens for light and electron microscopy. Histochem J. 1988;20(6-7):373-87. https://doi.org/10.1007/BF01002732.

91. Wang J, Hu M, Wang J, Qi J, Han Z, Wang G, et al. Reconstitution and structure of a plant NLR resistosome conferring immunity. Science (80- ). 2019;364(6435):eaav5870.

92. Ma S, Lapin D, Liu L, Sun Y, Song W, Zhang X, et al. Direct pathogeninduced assembly of an NLR immune receptor complex to form a holoenzyme. Science (80- ). 2020;370(6521):eabe3069.

93. Martin R, Qi T, Zhang H, Liu F, King M, Toth C, et al. Structure of the activated ROQ1 resistosome directly recognizing the pathogen effector XopQ. Science (80- ). 2020;370(6521):eabd9993.

94. Latz E, Xiao TS, Stutz A. Activation and regulation of the inflammasomes. Nat Rev Immunol. 2013;13(6):397-411. https://doi.org/10.1038/nri3452.

95. Saur IML, Panstruga R, Schulze-Lefert P. NOD-like receptor-mediated plant immunity: from structure to cell death. Nat Rev Immunol. 2020; https://doi. org/10.1038/s41577-020-00473-z.

96. Ambastha $\mathrm{V}$, Sopory SK, Tiwari BS, Tripathy BC. Photo-modulation of programmed cell death in rice leaves triggered by salinity. Apoptosis. 2017; 22(1):41-56. https://doi.org/10.1007/s10495-016-1305-7.

97. Araniti F, Costas-Gil A, Cabeiras-Freijanes L, Lupini A, Sunseri F, Reigosa MJ, et al. Rosmarinic acid induces programmed cell death in Arabidopsis seedlings through reactive oxygen species and mitochondrial dysfunction. PLoS One. 2018;13(12):e0208802. https://doi.org/10.1371/journal.pone.02 08802.

98. Ghasemi R, Sharifi R, Ghaderian SM. Studying the roles of calcium and magnesium in cell death in the serpentine native plant Alyssum inflatum NYÁRÁDY through cell suspension culture technique. Plant Physiol Biochem PPB. 2020;151:362-8. https://doi.org/10.1016/j.plaphy.2020.03.032.

99. Ryerson DE, Heath MC. Cleavage of nuclear DNA into oligonucleosomal fragments during cell death induced by fungal infection or by abiotic treatments. Plant Cell. 1996;8(3):393-402. https://doi.org/10.2307/3870320.
100. Navarre DA, Wolpert TJ. Victorin induction of an apoptotic/senescence-like response in oats. Plant Cell. 1999;11(2):237-49. https://doi.org/10.1105/ tpc.11.2.237.

101. Houot V, Etienne P, Petitot AS, Barbier S, Blein JP, Suty L. Hydrogen peroxide induces programmed cell death features in cultured tobacco BY-2 cells, in a dose-dependent manner. J Exp Bot. 2001;52(361):1721-30.

102. Behboodi BS, Samadi L. Detection of apoptotic bodies and oligonucleosomal DNA fragments in cadmium-treated root apical cells of Allium cepa Linnaeus. Plant Sci. 2004;167(3):411-6. https://doi.org/10.1016/j. plantsci.2004.04.024.

103. Tada Y, Kusaka K, Betsuyaku S, Shinogi T, Sakamoto M, Ohura Y, et al. Victorin triggers programmed cell death and the defense response via interaction with a cell surface mediator. Plant Cell Physiol. 2005;46(11):178798. https://doi.org/10.1093/pcp/pci193.

104. Lytvyn DI, Yemets Al, Blume YB. UV-B overexposure induces programmed cell death in a BY-2 tobacco cell line. Environ Exp Bot. 2010;68(1):51-7. https://doi.org/10.1016/j.envexpbot.2009.11.004.

105. Rybaczek D, Musiałek MW, Balcerczyk A. Caffeine-induced premature chromosome condensation results in the apoptosis-like programmed cell death in root meristems of Vicia faba. PLoS One. 2015;10(11):e0142307. https://doi.org/10.1371/journal.pone.0142307.

106. Nyalugwe EP, Barbetti MJ, Clode PL, Jones RAC. Programmed cell death pathways induced by early plant-virus infection are determined by isolate virulence and stage of infection. Plant Pathol. 2016;65(9):1518-28. https:// doi.org/10.1111/ppa.12533.

107. Dauphinee AN, Cardoso C, Dalman K, Ohlsson JA, Fick SB, Robert S, Hicks GR, Bozhkov PV, Minina EA. Chemical screening pipeline for identification of specific plant autophagy modulators. Plant Physiol. 2019;181(3):855-66. https://doi.org/10.1104/pp.19.00647.

108. Minina EA, Filonova LH, Sanchez-Vera V, Suarez MF, Daniel G, Bozhkov PV. Detection and measurement of necrosis in plants. In: McCall K, Klein C, editors. . Totowa: Humana Press; 2013. p. 229-48.

\section{Publisher's Note}

Springer Nature remains neutral with regard to jurisdictional claims in published maps and institutional affiliations.

Ready to submit your research? Choose BMC and benefit from

- fast, convenient online submission

- thorough peer review by experienced researchers in your field

- rapid publication on acceptance

- support for research data, including large and complex data types

- gold Open Access which fosters wider collaboration and increased citations

- maximum visibility for your research: over 100M website views per year

At $\mathrm{BMC}$, research is always in progress.

Learn more biomedcentral.com/submissions 